\title{
2. PALYNOLOGICAL BIOSTRATIGRAPHY, DEEP SEA DRILLING PROJECT SITES 367 AND 370
}

\author{
G.L. Williams, Atlantic Geoscience Centre, Geological Survey of Canada, \\ Bedford Institute, Dartmouth, Nova Scotia, Canada
}

\section{INTRODUCTION}

Samples from Sites 367 and 370, Leg 41 of the Deep Sea Drilling Project (Figure 1), were analyzed for palynological biostratigraphy. The oldest sediments cored and dated from Site 367 are OxfordianKimmeridgian according to the foraminiferal data. They are overlain by Tithonian, Cretaceous, and Tertiary sediments. Palynomorph recovery has been somewhat disappointing from Site 367. Site 370 bottoms in Neocomian sediments. A major hiatus apparently occurs between 673 and 663.5 meters where Paleocene sediments appear to overlie Cenomanian sediments. There is a more or less complete Tertiary sequence. Palynomorphs, and especially dinoflagellates, are abundant throughout Site 370 .

\section{BIOSTRATIGRAPHY}

\section{Site 367}

Site 367 is located in 4748 meters of water in the Cape Verde Basin to the west of Senegal. It was drilled to compare the Mesozoic section in the eastern North Atlantic with that of the western Atlantic, as found in part on the Scotian Shelf and the Grand Banks. The hole bottomed in basalt at 1153 meters. Sequentially overlying the basalt are upper Jurassic through Pleistocene sediments. The dinoflagellates, spores, and pollen present in these sediments are listed in Figure 2 and discussed below.

\section{Jurassic}

The interval 1148-1081.5 meters at Site 367 has been dated late Jurassic from the foraminiferal data. Limestones predominate in this interval (Jansa, this volume), probably accounting for the absence of palynomorphs in 7 of the 11 samples examined. However, diagnostic assemblages in Cores 367-38 and 367-35 have been dated as Kimmeridgian. The only spores present are the ubiquitous species Callialasporites dampieri (Balme) Dev, Cicatricosisporites australiensis (Cookson) Potonié, and Corollina torosus (Reissinger) Klaus. The dinocysts include Epiplosphaera bireticulata Klement, Prolixosphaeridium mixtispinosum (Klement) Davey, Scriniocassis dictyotum (Cookson and Eisenack) Beju, Sirmiodinium grossi Alberti sensu Gitmez and Sarjeant, 1972, Systematophora fasciculigera Klement, and $S$. turonica (Alberti) Downie and Sarjeant (Figure 2). E. bireticulata, $P$. mixtispinosum, and $S$. grossi sensu Gitmez and Sarjeant are known only from the

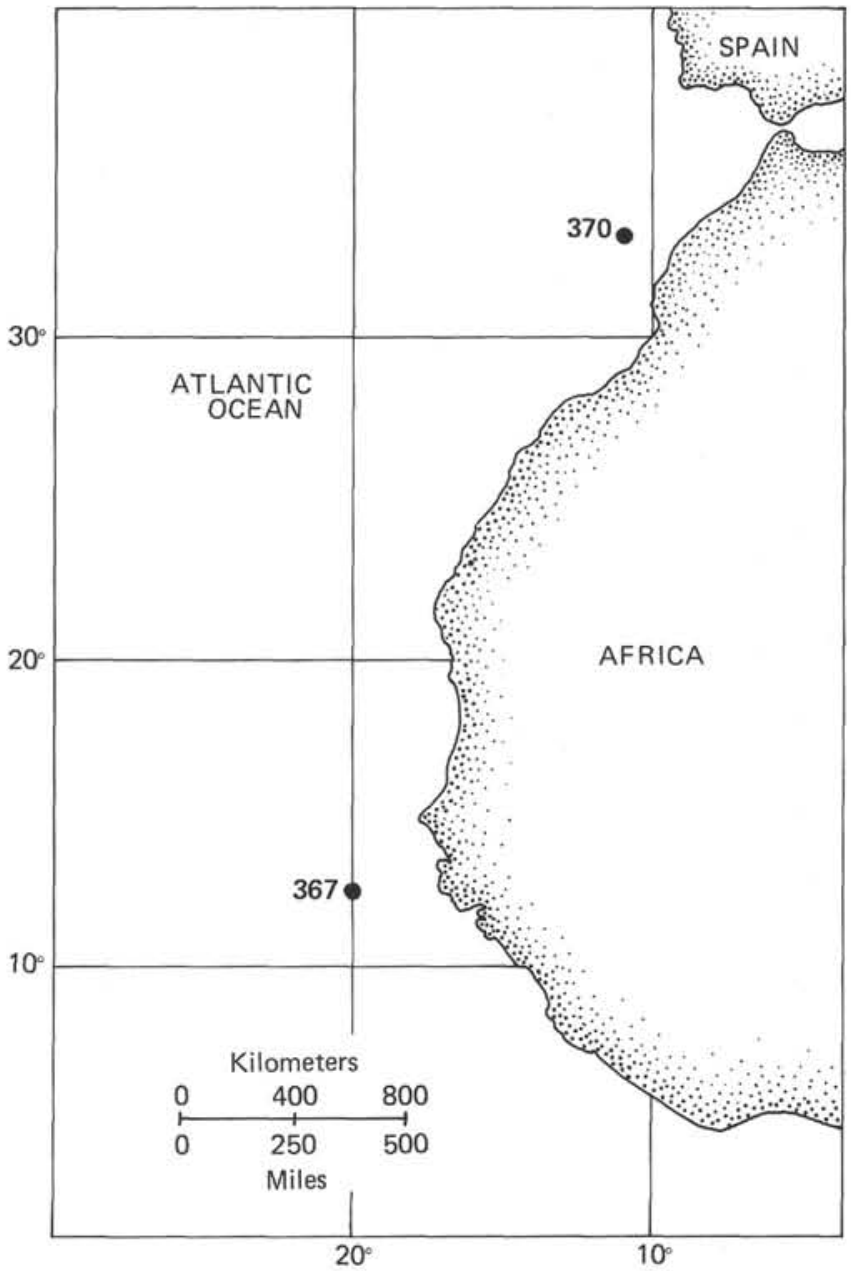

Figure 1. Location map DSDP Sites 367 and 370.

Kimmeridgian (Sarjeant, 1975). S. dictyotum, which according to Habib (1972) extends into the Valanginian of DSDP Site 105, ranges from Aalenian to Kimmeridgian and questionably into the early Cretaceous according to Sarjeant (1975). This species has not been recorded from Jurassic sediments of the Scotian Shelf. Systematophora turonica was originally described from the Turonian by Alberti (1961). In the Scotian Shelf sediments, however, it is not found above the Kimmeridgian. It is probable that Alberti was describing reworked material. The dinocyst assemblage in these cores is assigned a Kimmeridgian age.

The dinocyst species present in Core 367-32 (1091$1081.5 \mathrm{~m}$ ) include Ctenidodinium panneum (Norris) Lentin and Williams. This species is known only from 


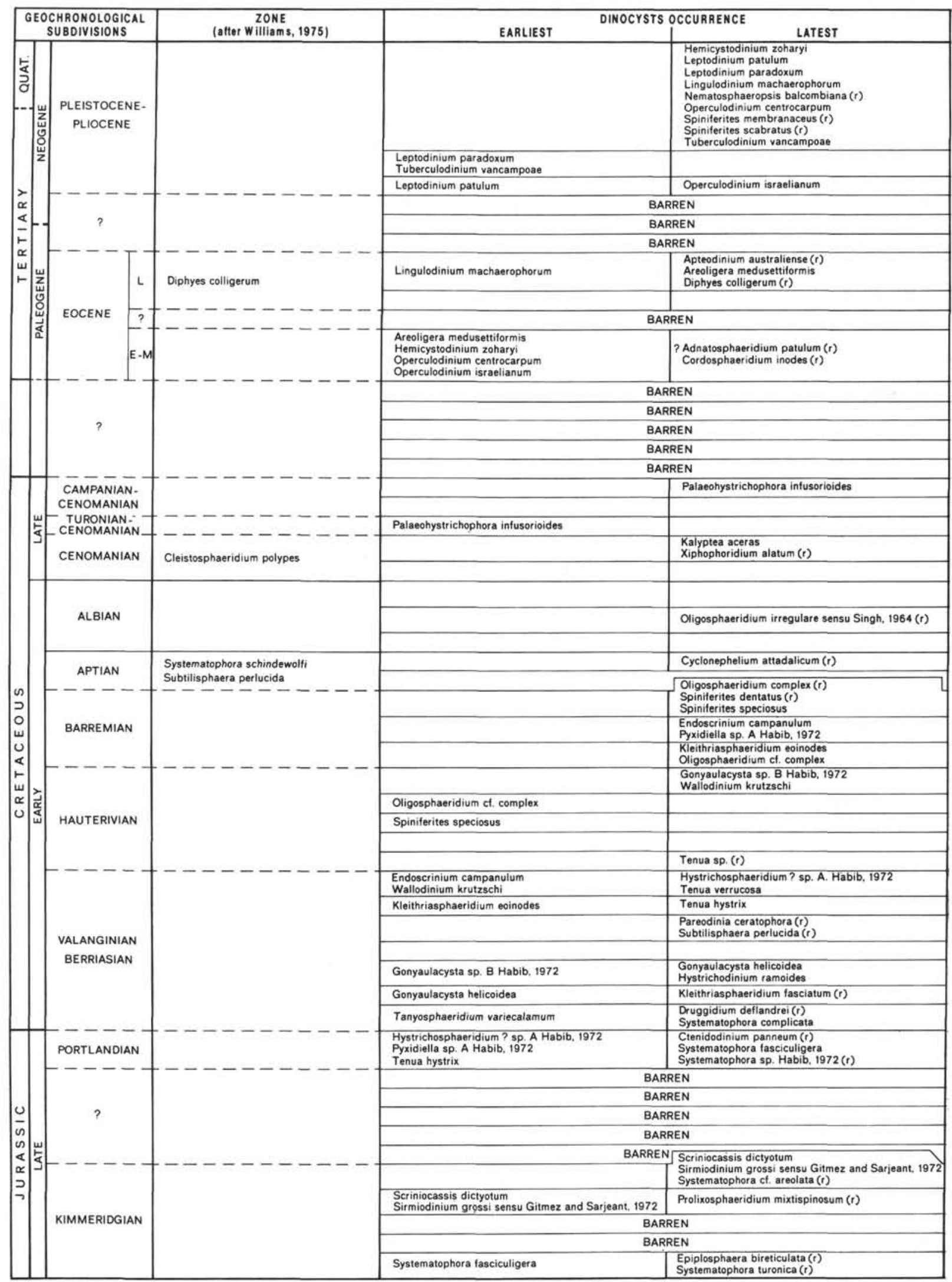

(r) PRESENT IN ONE SAMPLE ONLY

Figure 2. Dinocyst occurrences in DSDP Site 367. 


\begin{tabular}{|c|c|c|c|c|}
\hline \multirow[t]{8}{*}{$\begin{array}{l}\text { SPORES AND POLLEN } \\
\text { LATEST OCCURRENCE }\end{array}$} & $\begin{array}{c}\text { INTERVAL } \\
(\mathrm{cm})\end{array}$ & SECTION C & CORE & $\begin{array}{c}\text { CORE } \\
\text { DEPTH (m) }\end{array}$ \\
\hline & $30-32$ & 6 & 1 & 0.8 \\
\hline & $80-82$ & 3 & 2 & $8-17.5$ \\
\hline & $86-87$ & 2 & 3 & $54-63.5$ \\
\hline & $52-54$ & 3 & 4 & $63.5-73$ \\
\hline & $118-119$ & 1 & 5 & $150-160$ \\
\hline & $78-79$ & 1 & 6 & $236-245.5$ \\
\hline & $39-40$ & \multirow[t]{2}{*}{3} & \multirow[t]{2}{*}{8} & \multirow[t]{2}{*}{ 302.5-312 } \\
\hline Nyssapollenites sp. & $40-41$ & & & \\
\hline & $74-75$ & 1 & 9 & $331-340.5$ \\
\hline & $142-143$ & \multirow[t]{2}{*}{1} & \multirow[t]{2}{*}{12} & \multirow[t]{2}{*}{ 359.5-369 } \\
\hline & $146-147$ & & & \\
\hline & $103-104$ & 3 & 13 & $369-378.5$ \\
\hline & $20-21$ & 3 & 14 & $378.5-388$ \\
\hline & $75-76$ & 3 & 15 & $473.5-483$ \\
\hline & $116-118$ & 3 & 16 & $540-549.5$ \\
\hline & $95-96$ & 3 & 17 & $616-625.5$ \\
\hline & $101-103$ & 3 & 19 & $644.5-654$ \\
\hline \multirow[t]{3}{*}{ Corollina torosus } & $44-45$ & 3 & 21 & $692-701.5$ \\
\hline & $67-68$ & \multirow[t]{2}{*}{3} & \multirow[t]{2}{*}{22} & \multirow[t]{2}{*}{$720.5-730$} \\
\hline & $93-94$ & & & \\
\hline $\begin{array}{l}\text { lensoisporites perinatus } \\
\text { Equisetosporites sp. }\end{array}$ & $62-63$ & \multirow{2}{*}{2} & \multirow{3}{*}{23} & \multirow{3}{*}{$777.5-787$} \\
\hline \multirow[t]{2}{*}{$\begin{array}{l}\text { Alisporites grandis } \\
\text { Leptolepidites psarosus }\end{array}$} & $139-140$ & & & \\
\hline & CORE & CATCHER & & \\
\hline \multirow[t]{2}{*}{ Callialasporites dampieri } & $12-13$ & \multirow{2}{*}{3} & \multirow{2}{*}{24} & \multirow{2}{*}{$834.5-844$} \\
\hline & 98-99 & & & \\
\hline Callialasporites segmentus & $20-21$ & \multirow{3}{*}{4} & \multirow{3}{*}{25} & \\
\hline Callialasporites trilobatus & $79-81$ & & & 891.5-901 \\
\hline & $81-82$ & & & \\
\hline & $72-74$ & 3 & 1 & \\
\hline & $31-32$ & 4 & 26 & $910.5-920$ \\
\hline & $52-54$ & ${ }^{4}$ & & \\
\hline & $79-81$ & 1 & 27 & $939-948.5$ \\
\hline & $107-108$ & 2 & & $939=948.5$ \\
\hline & $62-63$ & 1 & & \\
\hline & $110-112$ & & 28 & $967.5-977$ \\
\hline & $93-94$ & 3 & & \\
\hline & $95-96$ & 2 & 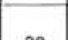 & Sog 1005 \\
\hline & 1.2 & 3 & 29 & $996-1005.5$ \\
\hline Contignisporites cooksonii & $13-14$ & 2 & 30 & $1024.5-1034$ \\
\hline & $1-2$ & 2 & 31 & $1053-1062.5$ \\
\hline & 44.45 & 2 & 32 & 1081.5-1091 \\
\hline & $106-107$ & 5 & & \\
\hline & $95-96$ & 2 & 33 & $1105.5-1111$ \\
\hline & $137-138$ & 2 & 2 & 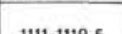 \\
\hline & $23-24$ & 4 & 34 & mIm-1m9.5 \\
\hline & 93-94 & 1 & & \\
\hline & $37-38$ & 5 & 35 & $1119.5-1127.5$ \\
\hline & $110-111$ & 5 & & \\
\hline & $13-14$ & 3 & 36 & $1127.5-1135$ \\
\hline & $61-62$ & 1 & 37 & $1135-1142$ \\
\hline & $27-29$ & 1 & 38 & $1142-1148$ \\
\hline
\end{tabular}

Figure 2. (Continued). the Portlandian of southern England (Norris, 1965) and the Scotian Shelf (Williams, 1975). For this reason Core $367-32$ is dated Portlandian.

\section{Cretaceous}

Cretaceous sediments extend from 1062.5 to 616 meters (Cores 367-31 to 367-17), of which 1062.5-777.5 meters (Cores 367-31 to 367-23) is lower Cretaceous, and the remainder is upper Cretaceous. Lithologically, there is a limestone-marlstone sequence with some shale from 1062.5 to 891.5 meters (Cores 367-31 to 36725 ), successively overlain by a variegated claystone from 844 to 834.5 meters (Core 367-24), a black shale from 787 to 636.0 meters (Cores $367-23$ to $367-18$ ), and a multicolored silty clay from 625.5 to 616 meters (Core $367-17)$ (Jansa, this volume). Palynomorphs are present in all but one sample, from Core 367-24.

Subdivision of the early Cretaceous is difficult, particularly in the Neocomian (here taken to exclude the Barremian), since there is little resemblance to assemblages from known localities. The BerriasianValanginian appears to extend from 1053 to 967.5 meters (Cores 367-31 to 367-28). Species present include Endoscrinium campanulum (Gocht) Vozzhennikova, Druggidium deflandrei (Millioud) Habib, Gonyaulacysta helicoidea (Eisenack and Cookson) Sarjeant, Gonyaulacysta sp. B Habib, 1972, Hystrichodinium ramoides Alberti, Hystrichosphaeridium sp. A Habib, 1972, Kleithriasphaeridium eoinodes (Eisenack) Davey, K. fasciatum (Davey and Williams) Davey, Subtilisphaera perlucida (Alberti) Jain, and Millepied, Tenua hystrix Eisenack, T. verrucosa Sarjeant and Wallodinium krutzschi (Alberti) Habib. Species not ranging up into the Hauterivian are Druggidium deflandrei, Gonyaulacysta helicoidea, Hystrichodinium ramoides, Hystrichosphaeridium sp. A, Kleithriasphaeridium fasciatum, Subtilisphaera perlucida, Tenua hystrix, and $T$. verrucosa. Endoscrinium campanulum, according to Millioud (1975) has a stratigraphic range of ValanginianTuronian. This species also first appears in the Valanginian in the Speeton Clay section of northeast England (personal observation). In the Scotian Shelf wells $E$. campanulum occurs, only rarely, above the Barremian. Druggidium deflandrei also first appears in the Valanginian (Millioud, 1975), although Habib (1972) recorded it as first appearing in the early Cretaceous, in strata overlain by probable Valanginian sediments. Both Habib (1972) and Millioud (1975) show Gonyaulacysta helicoidea as first appearing in the Barremian, and Eisenack and Cookson (1960) recorded it from Neocomian-Aptian, sediments. At Speeton it first appears in the Ryazanian. Gonyaulacysta sp. B and Hystrichosphaeridium sp. A were described from DSDP Sites 101 and 105 by Habib (1972). The sample from Site 105 containing Hystrichosphaeridium sp. A, which is dated late Jurassic-early Cretaceous, also contains Biorbifera johnewingi Habib. Although Millioud (1975) extends the range of this species up into the Hauterivian, it has never been found above the Valanginian on the Scotian Shelf (personal observation). Correlation with the Scotian Shelf would therefore suggest a Berriasian-Valanginian age for the association containing Hystrichosphaeridium sp. A at Site 105. 
The interval from which Gonyaulacysta sp. B was recovered at Site 105 is tentatively dated Valanginian by Habib (1972). Hystrichodinium ramoides is restricted to the Barremian by Millioud (1975). Kleithriasphaeridium fasciatum and Subtilisphaera perlucida first appear in the Ryazanian (Berriasian) and Valanginian, respectively, of the Speeton Clay. $K$. eoinodes has a known range of Berriasian-Albian (Millioud, 1975). At Speeton it appears in the Valanginian. Tenua hystrix and $T$. verrucosa are predominantly late Jurassic species. Habib (1972) recorded Wallodinium krutzschi from the Neocomian of Site 105.

Comparison of the above assemblage from Site 367 with the dinocysts recovered from Site 370 , where the Neocomian assemblages show marked similarity to those of the Scotian Shelf and permit subdivision into the Berriasian, Valanginian, and Hauterivian, provides support for a Berriasian-Valanginian age. At Site 370 , Gonyaulacysta helicoidea and Hystrichosphaeridium sp. $A$ are restricted to the Berriasian-Valanginian. The interval 1062.5-967.5 meters at Site 367 is accordingly dated Berriasian-Valanginian.

The Hauterivian is recognized between 948.5 and 910.5 meters at Site 367. Species first appearing are Oligosphaeridium cf. complex (White) Davey and Williams and Spiniferites speciosus (Deflandre) Sarjeant, while Gonyaulacysta sp. B Habib, 1972, and Wallodinium krutzschi do not range into younger sediments. W. krutzschi has a range of ValanginianHauterivian at Site 370. The highest occurrence of this species at $920-910.5$ meters is therefore taken to mark the top of the Hauterivian at Site 367.

Several species are not present above the Barremian, which extends from 901 to 891.5 meters. These include Endoscrinium campanulum, Kleithriasphaeridium eoinodes (Eisenack) Davey, Pyxidiella sp. A Habib, 1972, Oligosphaeridium cf. complex, Spiniferites dentatus (Gocht) Lentin and Williams, and S. speciosus. $K$. eoinodes, according to Millioud (1975) has a known range of Berriasian-Albian, although in the Scotian Shelf sediments it is encountered very rarely in the postBarremian. This species is restricted to the Barremian at Site 370. Pyxidiella sp. A was recorded by Habib from the Barremian-Aptian of DSDP Site 101A. Spiniferites dentatus, originally described from the late Hauterivian by Gocht (1959), is restricted to the Berriasian-Barremian in the Scotian Shelf sediments. Comparison of the dinocyst assemblages in three samples from Core $367-25$ (901-891.5 m) with those in the Barremian of Site 370 and the Scotian Shelf supports the Barremian age determination.

The interval 844-834.5 meters (Core 367-24) is dated Aptian. The index species Cyclonephelium attadalicum, common in the type Aptian (recorded as Cyclonephelium tabulatum by Davey and Verdier, 1974) and present in the Aptian of several wells on the Scotian Shelf, occurs in large numbers. The spore Callialasporites dampieri (Balme) Dev, also present in Core $367-24$, is absent from post-Aptian sediments on the Scotian Shelf (Williams, 1975).

The youngest stage in the Early Cretaceous, the Albian, is recognized between 787 and 777.5 meters in Core $367-23$. Dinocysts are not abundant with only one diagnostic taxon, Oligosphaeridium irregulare (Pocock)
Davey and Williams sensu Singh (1964) (as Hystrichosphaeridium) being present. Spores species include Alisporites grandis (Cookson) Dettmann, Densoisporites velatus Weyland and Krieger, Equisetosporites sp., and Leptolepidites psarosus Norris. $A$. grandis is unknown from post-Albian deposits according to Singh (1971). L. psarosus was originally described from the Portlandian. The dinocyst Oligosphaeridium irregulare has a known range of Barremian-Albian. Core $367-23$ is therefore dated Albian.

Recovery of palynomorphs from the Late Cretaceous black shales is poor, with few dinocysts or pollen. Age determinations are therefore imprecise above 701.5-692 meters (Core 367-21). The interval 730-720.5 meters (Core 367-22) contains the dinocyst species Kalyptea aceras Manum and Cookson and Xiphophoridium alatum (Cookson and Eisenack) Sarjeant. X. alatum has a known range of Aptian-Cenomanian (Davey, 1970). Also present is the pollen species Corollina torosus (Reissinger) Klaus, which in the Scotian Shelf-Grand Banks wells has a stratigraphic range of HettangianTuronian. The presence of this species in the interval 701.5-692 meters (Core 367-21), together with Palaeohystrichophora infusorioides Deflandre, indicates a Cenomanian, possibly Turonian age. $P$. infusorioides, according to Davey (1970), first appears in the Cenomanian. Millioud (1975) and Williams (1975), however, give it a range of late Albian-Campanian, while Davey and Verdier (1973) recorded it from the type Vraconian section of late Albian age.

The interval 654-616 meters (Cores 367-19 and 36717) can only be dated Cenomanian-Campanian since the only diagnostic palynomorph present is Palaeohystrichophora infusorioides. Cores 367-16 through 367-13 (549.5-369 m) do not contain palynomorphs. Lithologically, Cores $367-16$ to $367-14$ are a multicolored silty clay; Cores $367-14$ to $367-13$ are zeolitic clays.

\section{Tertiary}

Tertiary dinocysts first appear in the interval 369359.5 meters (Core 367-12) of the zeolitic clay. Species include ?Adnatosphaeridium patulum Williams and Downie, Areoligera medusettiformis LejeuneCarpentier, Cordosphaeridium inodes (Klumpp) Eisenack, and Hemicystodinium zoharyi (Rossignol) Wall. ?A. patulum, originally described from the early Eocene, is present in the middle Eocene of Site 370. A. medusettiformis appears for the last time in the late Eocene of the Scotian Shelf. Hemicystodinium zoharyi has a known range of early Eocene to Recent (Williams, 1975; Wall and Dale, 1969). This interval is therefore dated early to middle Eocene.

Cores 367-9 through 367-1 are lithologically subdivided into zeolitic clay (Core 367-9, 340.5-331 m), diatom-bearing radiolarian clay (Core 367-8, 312-302.5 $\mathrm{m}$ ), and alternating nanno marls and silty clays (Cores $367-7$ to $367-1,302.5-0 \mathrm{~m}$ ) (Jansa, this volume). The interval 340.5-331 meters (Core 367-9) is devoid of dinocysts. Core 367-8 (312-302.5 m) however, contains several diagnostic species and can be dated late Eocene. Apteodinium australiense (Deflandre and Cookson) comb. nov., is present, together with Areoligera 
medusettiformis, Diphyes colligerum (Deflandre and Cookson) Cookson, and Lingulodinium machaerophorum (Deflandre and Cookson) Wall. $A$. australiense has a stratigraphic range of late Eocene to early Miocene in DSDP Sites 1 through 6 . Williams and Brideaux (1975) who recorded this species as Apteodinium sp. Gocht (1969), observed it in late Eocene-late Miocene sediments. D. colligerum is used as a late Eocene zonal index species by Williams (1975), who plotted a late Paleocene-late Eocene range for it. The assemblage is therefore regarded as late Eocene.

Cores 367-6 through 367-4 (245.5-63.5 m) are barren. They are overlain by Plio-Pleistocene sediments containing dinocysts and extending from 63.5 to 0 meters (Cores 367-3 through 367-1). Species present include Leptodinium patulum Wall, $L$. paradoxum Wall, Nematosphaeropsis balcombiana Deflandre and Cookson, Spiniferites membranaceus (Rossignol) Sarjeant, S. scabratus (Wall) Sarjeant, and Tuberculodinium vancampoae (Rossignol) Wall. This assemblage compares favorably with those described from Pleistocene cores in the Caribbean Sea by Wall (1967).

\section{Conclusions}

The oldest sediments dated palynologically are Kimmeridgian. These are overlain by Portlandian sediments, the total thickness of the Upper Jurassic being approximately 66 meters. There is a more or less complete Lower Cretaceous section extending from 1062.5 to 777.5 meters. The Upper Cretaceous is imperfectly known because of the absence of palynomorphs in several of the samples. Although recovery is also spasmodic in the Cenozoic, Eocene and Plio-Pleistocene sediments can be differentiated. In the majority of samples the dinocysts predominate. Spores and pollen are most abundant in the Lower Cretaceous, and are sparse or absent in the Upper Cretaceous and Tertiary. Comparison of the assemblages with the Scotian Shelf-Grand Banks shows similarities, particularly in the Lower Cretaceous. It is, however, impossible to draw any conclusions due to the overall sparseness of the assemblages. Throughout, reworked material was minimal.

\section{Site 370}

Site 370 is located in 4214 meters of water in the basin off the northwestern Moroccan continental margin. The core hole bottomed in a Lower Cretaceous claystone-marl siltstone sequence at 1176.5 meters. There is a well-developed Lower Cretaceous section, over 400 meters thick, overlain by approximately 65 meters of Cenomanian, which extends from 739.5 to 673 meters. Samples are not available from 673 to 644.5 meters where the sediments are probably of early Eocene age. This is succeeded by middle Eocene, late Eocene, Oligocene, early Miocene, middle Miocene, ?late Miocene, and Plio-Pleistocene sediments, respectively (Figure 3). Dinocysts are abundant throughout, with the assemblages showing a marked similarity to coeval assemblages from the Scotian Shelf. Reworked material is common, particularly in the Tertiary where it sometimes represents up to $30 \%$ of the palynomorph count. Spores and pollen are rare.

\section{Cretaceous}

The Cretaceous extends from 1167 to 673 meters (Cores $370-50$ to $370-20$ ), of which 418 meters are Lower Cretaceous sediments, and 66.5 meters (Cores $370-26$ to 370-20) Cenomanian (Figure 3). Jansa (this volume) places this interval in his Unit 5 , a sequence of nannofossil-bearing claystones, silty claystones with interbedded siltstone and sandstone, and occasional conglomerates. The oldest sediments, palynologically dated as Berriasian-Valanginian, are present from 1167 to 986.5 meters (Cores $370-50$ to $370-41$ ). Species appearing for the first time include Cribroperidinium muderongense sensu Habib, 1972, C. orthoceras (Eisenack) Davey, Cyclonephelium distinctum Deflandre and Cookson, $C$. vannophorum Davey, Meiourogonyaulax stoveri Millioud, Occisucysta sp. A, Oligosphaeridium complex (White) Davey and Williams, Oligosphaeridium cf. complex, Oligosphaeridium dividuum sp. nov., Pseudoceratium pelliferum Gocht, Spiniferites ramosus (Ehrenberg) Loeblich and Loeblich, and Wallodinium krutzschi Alberti) Habib. Species restricted to this interval are Achomosphaera neptuni (Eisenack) Davey and Williams, Endoscrinium campanulum (Gocht) Vozzhennikova, Gonyaulacysta helicoidea (Eisenack and Cookson) Sarjeant, Hystrichosphaeridium sp. A Habib, 1972, Lanterna sportula Dodekova, Phoberocysta neocomica (Gocht) Millioud, and Spiniferites speciosus (Deflandre) Sarjeant (Figures 3 and 4). Cribroperidinium orthoceras, which is present in the bottom Core 370-50, at 1167-1157.5 meters, has a stratigraphic range of Valanginian-Cenomanian (Millioud, 1975). In the Speeton Clay section it first appears in the Valanginian, indicating that the oldest dated sediments at Site 370 are Valanginian, rather than Berriasian. Cyclonephelium distinctum, also present in Core 370-50, first occurs in the Valanginian according to Millioud (1975). The range of $C$. vannophorum is imperfectly known, although Williams (1975) recorded it from Hauterivian to Coniacian sediments on the Scotian Shelf. Combining the data from Millioud (1975) and Williams (1975) would result in a Kimmeridgian-Aptian range for Meiourogonyaulax stoveri. Pseudoceratium pelliferum, a ubiquitous species originally described from the Valanginian-Hauterivian by Gocht (1957), is restricted to the ValanginianBarremian. This species occurs in large numbers in Core 370-44 (1053-1043.5 m). Wallodinium krutzschi, described by Alberti (1961) from the HauterivianBarremian, has never been recorded from Jurassic sediments. Perhaps more significant than the above are the presence of Achomosphaera neptuni and Phoberocysta neocomica in this interval. Williams (1975) defined a $P$. neocomica Zone which he recognized in several wells on the Scotian Shelf and to which he assigned a Berriasian-Valanginian age. Both $P$. neocomica and $A$. neptuni are restricted to this zone. The evidence for dating the interval 1167-986.5 meters (Cores $370-50$ to $370-41$ ) at Site 370 BerriasianValanginian, and perhaps more correctly Valanginian, is therefore strengthened by comparison with the Scotian Shelf assemblages. The reworked species present in these and subsequent cores will be discussed under a separate heading. 


\begin{tabular}{|c|c|c|c|c|c|c|c|c|c|c|}
\hline \multicolumn{3}{|c|}{$\begin{array}{l}\text { GEOCHRONOLOGICAL } \\
\text { SUBDIVISIONS }\end{array}$} & $\begin{array}{l}\text { ZONE } \\
\text { (atter Williams, 1975) }\end{array}$ & \multicolumn{2}{|c|}{ DINOFLAGELLATES OCCURRENCE } & $\begin{array}{l}\text { COMMON } \\
\text { (more than 10) }\end{array}$ & $\begin{array}{c}\text { INTERVAL } \\
(\mathrm{cm})\end{array}$ & SECTION & CORE & $\begin{array}{c}\text { CORE DEPTH } \\
(\mathrm{m})\end{array}$ \\
\hline \begin{tabular}{l|l} 
\\
$\bar{a}$ \\
$\vdots$ \\
0
\end{tabular} & $\begin{array}{l}\text { PLEISTOCEN } \\
\text { PLIOCENE }\end{array}$ & & & & 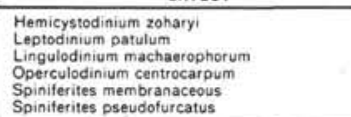 & $\begin{array}{l}\text { Lingulodinium machaerophorum } \\
\text { Operculodinium centrocarpum }\end{array}$ & 80.82 & 3 & , & 0.8 \\
\hline \multirow{3}{*}{ 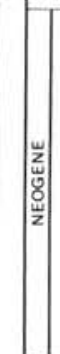 } & \multirow{3}{*}{ MIOCENE } & $M-L$ & & & 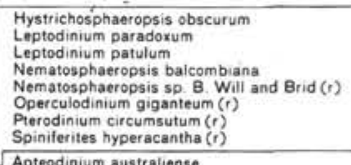 & $\begin{array}{l}\text { Leptodinium patulum } \\
\text { Operculodinium centrocarpum }\end{array}$ & 133.135 & ' & 2 & $103-112.5$ \\
\hline & & M & & $\begin{array}{l}\text { Hystrichosphaseropsis obscurum } \\
\text { Loptodinium paradoxum }\end{array}$ & 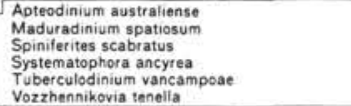 & $\begin{array}{l}\text { Apteodinium australiense } \\
\text { Aystrichosphaeropsis obscurum } \\
\text { Spinitertites scabratus }\end{array}$ & $78 \cdot 80$ & 2 & 3 & $2075-217$ \\
\hline & & E & & & 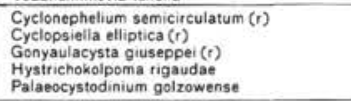 & & $61-63$ & 3 & 4 & 217.226 .5 \\
\hline \multirow{8}{*}{$\begin{array}{l}\gamma \\
\alpha \\
\alpha \\
\\
\alpha \\
\alpha \\
w \\
-1\end{array}$} & \multicolumn{2}{|c|}{ OLIGOCENE } & Chiropteridium dispersum & $\begin{array}{l}\text { Spiniterites scabratus } \\
\text { Tuberculodinium vancampose }\end{array}$ & 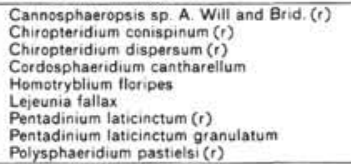 & $\begin{array}{l}\text { Chiropteridium conispinum } \\
\text { Chinotoridium dispersum } \\
\text { Hemicystodotinum zoharyi }\end{array}$ & $108-110$ & 1 & 5 & $321.5-331$ \\
\hline & \multirow{7}{*}{ EOCENE } & \multirow{3}{*}{ L } & \multirow{3}{*}{ Diphyes colligerum } & 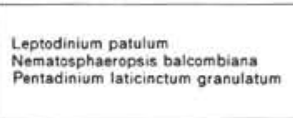 & 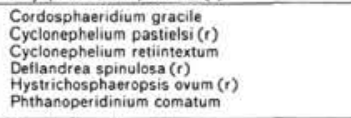 & & $68-69$ & i & 6 & $426-435.5$ \\
\hline & & & & Systematophora ancyrea & 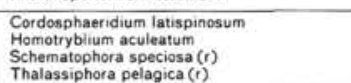 & & 88.90 & 2 & 7 & $445-454.5$ \\
\hline & & & & 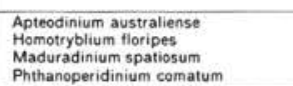 & 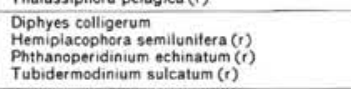 & Homotryblium aculeatum & $60-62$ & 2 & 8 & 464-473.5 \\
\hline & & \multirow[b]{2}{*}{ M } & \multirow[b]{2}{*}{ Adnatosphaeridium reticulense } & 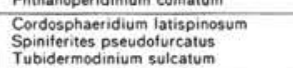 & 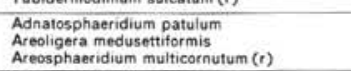 & $\begin{array}{l}\text { Adnatosphaeridium patulum } \\
\text { Dophyes colligerum } \\
\text { Homotryblium aculeatum }\end{array}$ & $98-100$ & 2 & 14 & 568.5 .578 \\
\hline & & & & 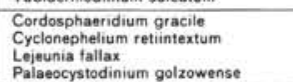 & 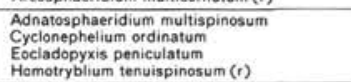 & $\begin{array}{l}\text { Hemicystodinium zoharyi } \\
\text { Homotryblium acuieatum }\end{array}$ & 130-132 & 3 & 15 & 587.5-597 \\
\hline & & \multirow[b]{2}{*}{ E } & \multirow[b]{2}{*}{ Areoligera senonensis } & 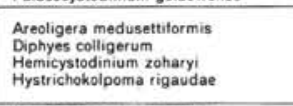 & 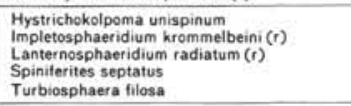 & Hystrichokolpoma unispinum & $98-100$ & ' & 17 & $616-625.5$ \\
\hline & & & & 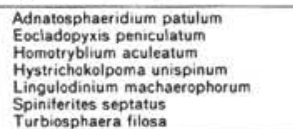 & 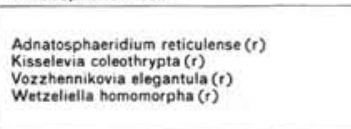 & & 54.56 & 2 & 18 & $635-644.5$ \\
\hline
\end{tabular}

Figure 3. Diagnostic species of the dinoflagellate zones in DSDP Site 370. 


\begin{tabular}{|c|c|c|c|c|c|c|c|c|c|}
\hline \multirow{8}{*}{ 这 } & \multirow{8}{*}{ CENOMAN } & \multirow{5}{*}{ Cleistosphaeridium polypes } & & 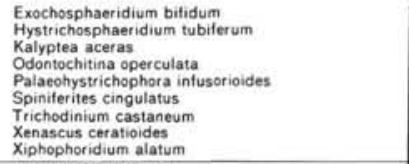 & Odontochitina operculata & 78.80 & 1 & 20 & $673-682.5$ \\
\hline & & & & $\begin{array}{l}\text { Odontochitina costata } \\
\text { Oligosphareativium complex } \\
\text { Tanyosphaeticium variecalamum }\end{array}$ & Xiphophoridium alatum & 68.70 & 3 & 20 & $673-682.5$ \\
\hline & & & & 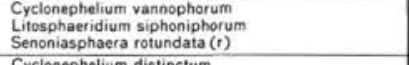 & 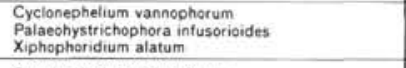 & $28 \cdot 30$ & 1 & \multirow[t]{2}{*}{21} & \multirow[t]{2}{*}{$682.5-692$} \\
\hline & & & & $\begin{array}{l}\text { Cyclonephelium distitichtum } \\
\text { Exochosphaeridium sp. }\end{array}$ & Cyclonephelium vannophorum & 68.70 & 2 & & \\
\hline & & & & 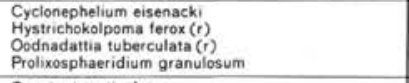 & $\begin{array}{l}\text { Exochosphaeridium bitidum } \\
\text { Odonotochtitina operculata }\end{array}$ & 79.81 & 1 & 22 & $692-701.5$ \\
\hline & & & & 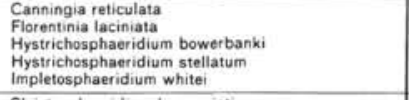 & $\begin{array}{l}\text { Cyclonephenelium vannophorum } \\
\text { xiphophoridium alatum }\end{array}$ & 78-80 & 3 & 23 & 701.5-711 \\
\hline & & & Xenascus ceratioides & 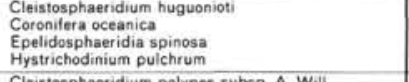 & & $78-80$ & 3 & 24 & 711.720 .5 \\
\hline & & & $\begin{array}{l}\text { Hystrichosphhaeridium stellatum } \\
\text { Palaeoohystrichophora intusarioides }\end{array}$ & $\begin{array}{l}\text { Cleistosp phaeridium polypes subsp A. Willi. } \\
\text { Ovviodininum scabrosum (I) }\end{array}$ & $\begin{array}{l}\text { Cleistosphaseridium polypes subsp. A. } \\
\text { Ovoidinium scabrosum }\end{array}$ & $78 \cdot 80$ & 2 & 26 & $730-739.5$ \\
\hline \multirow{6}{*}{ 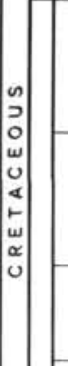 } & \multirow{3}{*}{ ALBIAN } & \multirow{3}{*}{ Spinidinium et. vestitum } & Litosphaeridium siphoniphorum & $\begin{array}{l}\text { Filerentibia radiculata } \\
\text { Polysphaeridium laminaspinosum } \\
\text { Fybpum }\end{array}$ & Oligosphaeridium complex & 88.90 & 1 & \multirow{2}{*}{27} & \multirow{2}{*}{$749-758.5$} \\
\hline & & & $\begin{array}{l}\text { Oodontochitina costata } \\
\text { Trichodinium castaneum }\end{array}$ & $\begin{array}{l}\text { Crtibropertidinium orthoceras } \\
\text { Palaeoperidinium cretaceum }\end{array}$ & Oligosphaeridium complex & 48.50 & 3 & & \\
\hline & & & 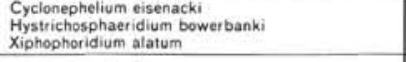 & $\begin{array}{l}\text { Gonyaulacysta cassidata } \\
\text { Spinidinium ct. vessitum (t) }\end{array}$ & Oligosphaeridium complex & 68.70 & 2 & 28 & $768-7775$ \\
\hline & \multirow{2}{*}{ APTIAN } & \multirow{2}{*}{$\begin{array}{l}\text { Systematophora schindewolfi } \\
\text { Subtilispheera perlucidaa }\end{array}$} & $\begin{array}{l}\text { Canningia reticulata } \\
\text { Polysphaseridium laminaspinosum }\end{array}$ & 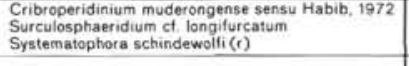 & Cribroperidiniumm muderongense sensu Habib, 1972 & $58-60$ & 4 & 30 & $806-815.5$ \\
\hline & & & $\begin{array}{l}\text { Clesistosphaeridium huguoniot } \\
\text { Florentinia radiculata } \\
\text { Prolinosphaseridium granulesum } \\
\text { Sppiniterites cingulatus }\end{array}$ & 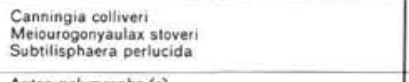 & Cribroperidinium muderongense sensu Habib, 1972 & 68.70 & 3 & at & $825-834.5$ \\
\hline & BARREMIAN & Tenua anaphrissa & $\begin{array}{l}\text { Cleistosphiaeridium polypes } \\
\text { Coronilera oceanical }\end{array}$ & 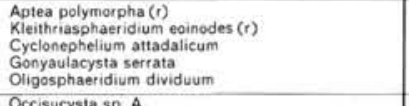 & Cyclonephelium atradalicum & $115-117$ & 1 & 32 & $834.5-844$ \\
\hline \multirow{9}{*}{ 迹 } & \multirow{4}{*}{ HAUTERIVIAN } & \multirow{4}{*}{ Ctenidodinium elegantulum } & Palaaoperidinium cretaceum & $\begin{array}{l}\text { Occisucysta sp. A } \\
\text { Pseudocertativm pelititerum }\end{array}$ & $\begin{array}{l}\text { Cyclonephelium attadalicum } \\
\text { Meiourogognyaulax stoveri }\end{array}$ & $78-80$ & 3 & 34 & $8725-882$ \\
\hline & & & Odontochitina operculata & $\begin{array}{l}\text { Callaiosphaseridium asymmetericum (r) } \\
\text { Oligosphaeridium \&. complex }\end{array}$ & $\begin{array}{l}\text { OCcciscusyla sp. A } \\
\text { Cyclonophelium attadaicum }\end{array}$ & $91-93$ & 1 & 35 & $882-891.5$ \\
\hline & & & 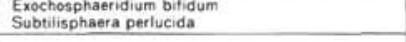 & Tenua hystrix & Oligosphateridium ct. complex & $113-115$ & 4 & 38 & 939-948.5 \\
\hline & & & $\begin{array}{l}\text { Cyclonephelium attadalicum } \\
\text { Gonyaulacysta serrata }\end{array}$ & 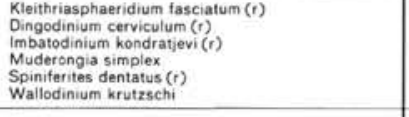 & Oligosphaeridium et. complex & 54.56 & 2 & 39 & 948 5.958 \\
\hline & \multirow{5}{*}{ VALANGINIAN } & \multirow{5}{*}{ Phoberocysta neocomica } & $\begin{array}{l}\text { Cyclonepepelium vannophorum } \\
\text { Sponititritios ramosusus } \\
\text { Wallodinium krutzschi }\end{array}$ & $\begin{array}{l}\text { Phoberocystat neoccomica } \\
\text { Spiniterites speciosus }\end{array}$ & & $115-117$ & 1 & 41 & $986.5-996$ \\
\hline & & & $\begin{array}{l}\text { Kalyptea aceras } \\
\text { Oliogsphaseridium complex } \\
\text { Pseudoceratium pelifiterum }\end{array}$ & Endoscrinium campanulum $(t)$ & Pseudoceratium pelliferum & 54.56 & 3 & 44 & 1043.5-1053 \\
\hline & & & 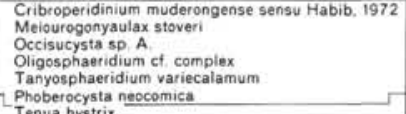 & 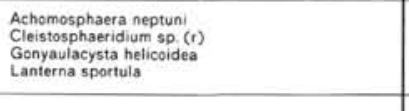 & Otigosphateridium dividuum & $108-110$ & 1 & 45 & 1062.5-1072 \\
\hline & & & Tenua hystrix & & & $70-72$ & $2^{2}$ & 48 & $1119.5-1129$ \\
\hline & & & 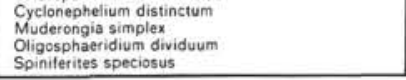 & Hystrichosphaeridium sp. A. Habib, 1972 (1) & & $85-87$ & ' & 50 & $1157.5-1167$ \\
\hline
\end{tabular}

Figure 3. (Continued). 


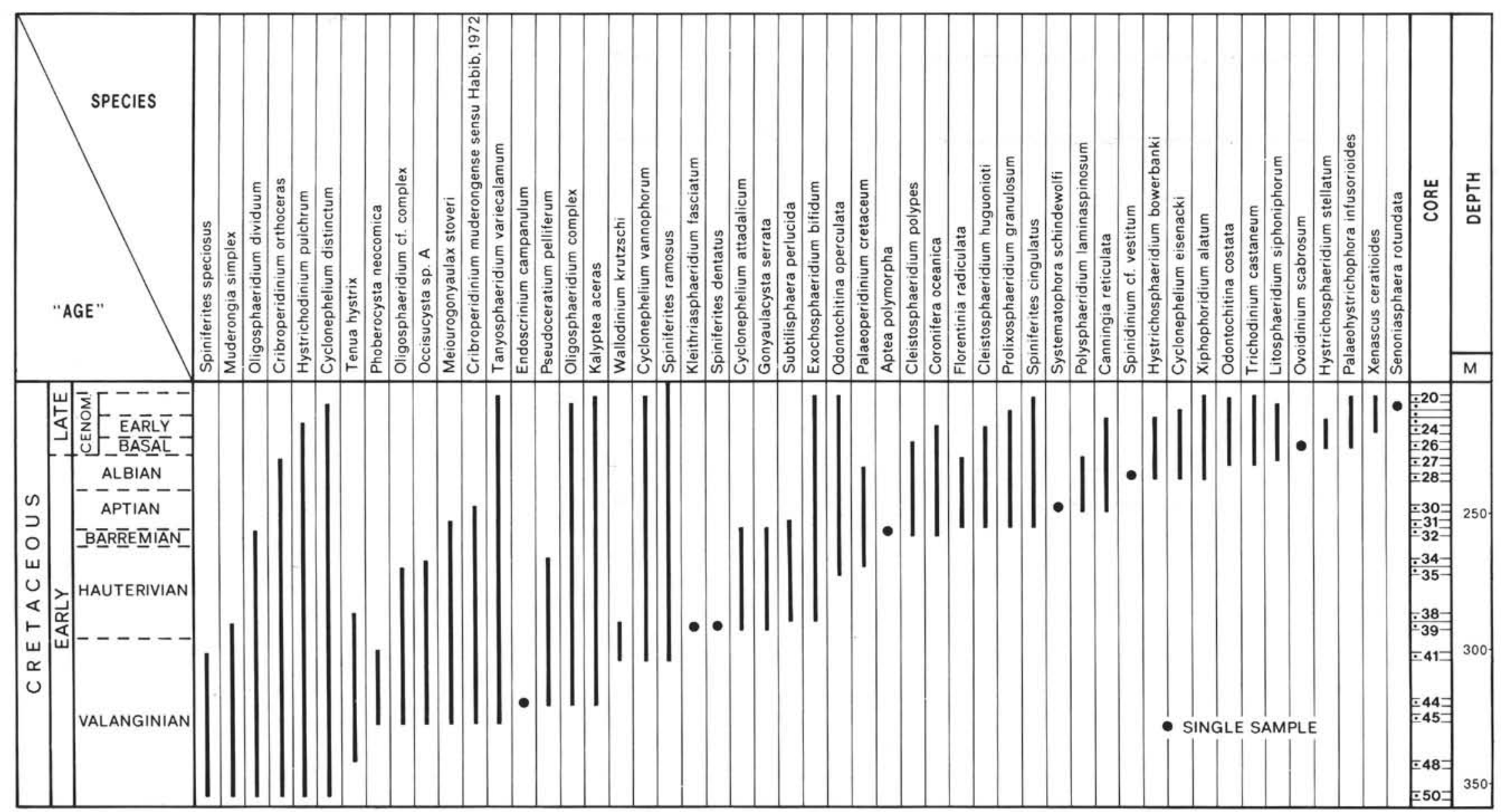

Figure 4. Stratigraphic ranges of selected dinocysts in the Cretaceous of DSDP Site 370. 
The Hauterivian, as indicated by palynological evidence, extends from 958 to 872.5 meters (Cores 37039 to 370-34) and contains several dinocyst species which also delineate the Hauterivian of the Scotian Shelf. Palaeoperidinium cretaceum Pocock and Davey, Cyclonephelium attadalicum Cookson and Eisenack, Gonyaulacysta serrata (Cookson and Eisenack) Sarjeant, and Odontochitina operculata (O. Wetzel) Deflandre and Cookson are first recorded from this interval. Williams (1975) noted that $C$. attadalicum had a stratigraphic range of Hauterivian-Aptian, and $G$. serrata last appeared in the Hauterivian in the Scotian Shelf sediments. Millioud (1975) recorded the earliest occurrence of $O$. operculata from the Hauterivian.

Confirmation of the Hauterivian age of this interval is provided by the presence of Dingodinium cerviculum Cookson and Eisenack, Imbatodinium kondratjevi Vozzhennikova, Kleithriasphaeridium fasciatum (Davey and Williams) Davey, Occisucysta sp. A, Pseudoceratium pelliferum, and Wallodinium krutzschi, none of which range into younger sediments. Occisucysta sp. A is present in the type Hauterivian section and in the Hauterivian of the Scotian Shelf and Grand Banks. D. cerviculum and I. kondratjevi do not range above the Hauterivian and $K$. fasciatum is Hauterivian-Barremian in the Scotian Shelf sediments. The interval 958-872.5 meters is therefore dated Hauterivian.

Core $370-32(844-834.4 \mathrm{~m})$ is tentatively dated Barremian because of the presence of Cleistosphaeridium polypes (Cookson and Eisenack) Davey, Kleithriasphaeridium eoinodes (Eisenack) Davey, Cyclonephelium attadalicum, Gonyaulacysta serrata, and Oligosphaeridium dividuum. The last named species does not range above the Barremian on the Scotian Shelf. There is a possibility however that Core 370-32 is early Aptian.

The Aptian extends from 834.5 to 806 meters (Cores 370-31 and 370-30). Correlations with coeval Scotian Shelf sediments is excellent. In both Site 370 and the Scotian Shelf wells, Canningia colliveri Cookson and Eisenack, Surculosphaeridium cf. longifurcatum (Firtion) Davey et al., Subtilisphaera perlucida (Alberti) Jain and Millepied, and Systematophora schindewolfi (Alberti) Downie and Sarjeant do not extend into younger sediments. Species first appearing are Canningia reticulata Cookson and Eisenack, Cleistosphaeridium huguonioti (Valensi) Davey, Florentinia radiculata (Davey and Williams) Davey, and Verdier and Polysphaeridium laminaspinosum Davey and Williams. Cribroperidinium muderongense sensu Habib (1972) is common in both Cores 370-31 and $370-30$. Oligosphaeridium complex is common in Core 370-30. C. muderongense according to Habib has a range of Barremian-Aptian in Sites 101A and 105.

The dinocyst assemblages of the Albian of the Scotian Shelf are frequently dominated by species of Oligosphaeridium. In Site $370, O$. complex is the most abundant species in the Albian which extends from 777.5 to 749 meters (Cores $370-28$ and 370-27). Other species present and which also characterize the Albian of the Scotian Shelf, are Palaeoperidinium cretaceum, Cyclonephelium eisenacki Davey, Cribroperidinium orthoceras, Florentinia radiculata, Litosphaeridium siphoniphorum (Cookson and Eisenack) Davey and Williams, Odontochitina costata Alberti, and Spinidinium cf. vestitum Brideaux. P. cretaceum, $F$. radiculata, and $L$. siphoniphorum have been recorded from the Albian of France by Davey and Verdier (1971, 1973). O. costata first appears in the Vraconian (late Albian) of France and Switzerland according to Davey and Verdier (1973). The Spinidinium cf. vestitum Zone in the Scotian Shelf sediments has been dated Albian, the taxon not having been recorded outside the Albian.

Species present in the Albian of Site 370, but uncommon in coeval sediments in the Scotian Shelf, are Gonyaulacysta cassidata (Eisenack and Cookson) Sarjeant, Trichodinium castaneum (Deflandre) Clarke and Verdier and Xiphophoridium alatum (Cookson and Eisenack) Sarjeant. All three are present in the Albian of France and Switzerland (Davey and Verdier, 1971, 1973).

Recognizable Upper Cretaceous sediments, all of Cenomanian age, occur between 739.5 and 673 meters (Cores 370-26 to 370-20). Subdivision into basal, early, and middle to late Cenomanian is possible, if the dinocyst assemblages are compared with those of England and, to a lesser extent, the Scotian Shelf. The sample from Core $370-26(739.5-730 \mathrm{~m})$ is dominated by Cleistosphaeridium polypes subsp. A of Williams (1975) and Ovoidinium scabrosum (Cookson and Hughes) Davey. C. polypes subsp. A is abundant in the Cenomanian of the Scotian Shelf. O. scabrosum was originally described from the late Albian-basal Cenomanian of southern England by Cookson and Hughes (1964). Davey (1970) believed that this species marked the base of the Cenomanian. The presence in the same sample of Palaeohystrichophora infusorioides strongly indicates a basal Cenomanian age for Core 370-26 (739.5-730 m).

The succeeding Cores 370-24 and 370-23 (720.5-701.5 m) contain Canningia reticulata Cookson and Eisenack, Cleistosphaeridium huguonioti, and Epelidosphaeridia spinosa (Cookson and Hughes) Davey. C. reticulata was not found above the early Cenomanian by Clarke and Verdier (1967). E. spinosa, according to Clarke and Verdier (1967) and Davey (1970), last appears in the middle Cenomanian. In the Scotian Shelf wells it also "tops" in the Cenomanian. The last occurrence of $C$. reticulata is taken as the top of the early Cenomanian at Site 367.

The interval 701.5-673 meters (Cores 370-22 to 37020 ) is middle to late Cenomanian. No new taxa appear but all the Cretaceous species disappear. These include Cyclonephelium vannophorum, Litosphaeridium siphoniphorum, Odontochitina costata, O. operculata, Palaeohystrichophora infusorioides, Trichodinium castaneum, Xenascus ceratioides, and Xiphophoridium alatum. The presence of the last named species in the topmost sample indicates that Core $\mathbf{3 7 0 - 2 0}$ is Cenomanian, since $X$. alatum has not been found in post Cenomanian sediments (Clarke and Verdier, 1967).

\section{Cenozoic}

Cenozoic sediments have been recognized between Cores $370-18$ and $370-1(644.5-0 \mathrm{~m})$. The oldest dated sediments are Eocene (644.5-426 m). These are 
succeeded by Oligocene (331-321.5 m), Miocene (226.5$103 \mathrm{~m})$, and Plio-Pleistocene (8-0 m). Unfortunately the individual cores are well spaced so that precise delineation of the boundaries is not possible. Lithologically, 644.5-208.5 meters (Cores $370-18$ to $370-3$ ) are nanno-bearing calcareous silty clays, porcellanite and chert with silt, sand and gravel beds, clayey nanno ooze, and silty marl (208.3-?0 m) and nannofossilforaminiferal bearing clay at the top (Jansa, this volume).

Within the Eocene, Cores 370-18 and 370-17 (644.5$616 \mathrm{~m}$ ) contain an early Eocene dinocyst assemblage. There is a marked influx of new species including ?Adnatosphaeridium patulum Williams and Downie, Areoligera medusettiformis (O. Wetzel) LejeuneCarpentier, Diphyes colligerum (Deflandre and Cookson) Cookson, Hemicystodinium zoharyi (Rossignol) Wall, Homotryblium aculeatum sp. nov., Hystrichokolpoma unispinum Williams and Downie, and Spiniferites septatus (Cookson and Eisenack) McLean (Figure 5). The last two species, together with Wetzeliella homomorpha, are restricted to this horizon. ?A. patulum, originally described from the early Eocene of southern England ranges into the middle Eocene on the Scotian Shelf. Areoligera medusettiformis has been recorded from Eocene sediments by Gocht (1969). Williams (1975) noted that $D$. colligerum ranged from the late Paleocene to late Eocene, while Spiniferites septatus appeared for the last time and Hemicystodinium zoharyi for the first time in the early Eocene. Hystrichokolpoma unispinum is restricted to the early Eocene (Williams and Downie, 1966). The interval $644.5-616$ meters (Cores $370-18$ and $370-17$ ) is therefore dated early Eocene.

Cores 370-15 and 370-14 (597-568.5 m) are assigned to the middle Eocene because of the presence of (?)Adnatosphaeridium patulum, A. multispinosum Williams and Downie, Areosphaeridium multicornutum Eaton, Eocladopyxis peniculatum, and Tubidermodinium sulcatum Morgenroth. Areosphaeridium multicornutum described by Eaton (1971) from the middle Eocene of southern England, extends into the early Oligocene on the Grand Banks, as does Eocladopyxis peniculatum, originally described from the early Eocene by Morgenroth (1966a). Tubidermodinium sulcatum, although described from the early Eocene by Morgenroth, first appears in the middle Eocene on the Scotian Shelf, and extends into the late Oligocene. ?A.

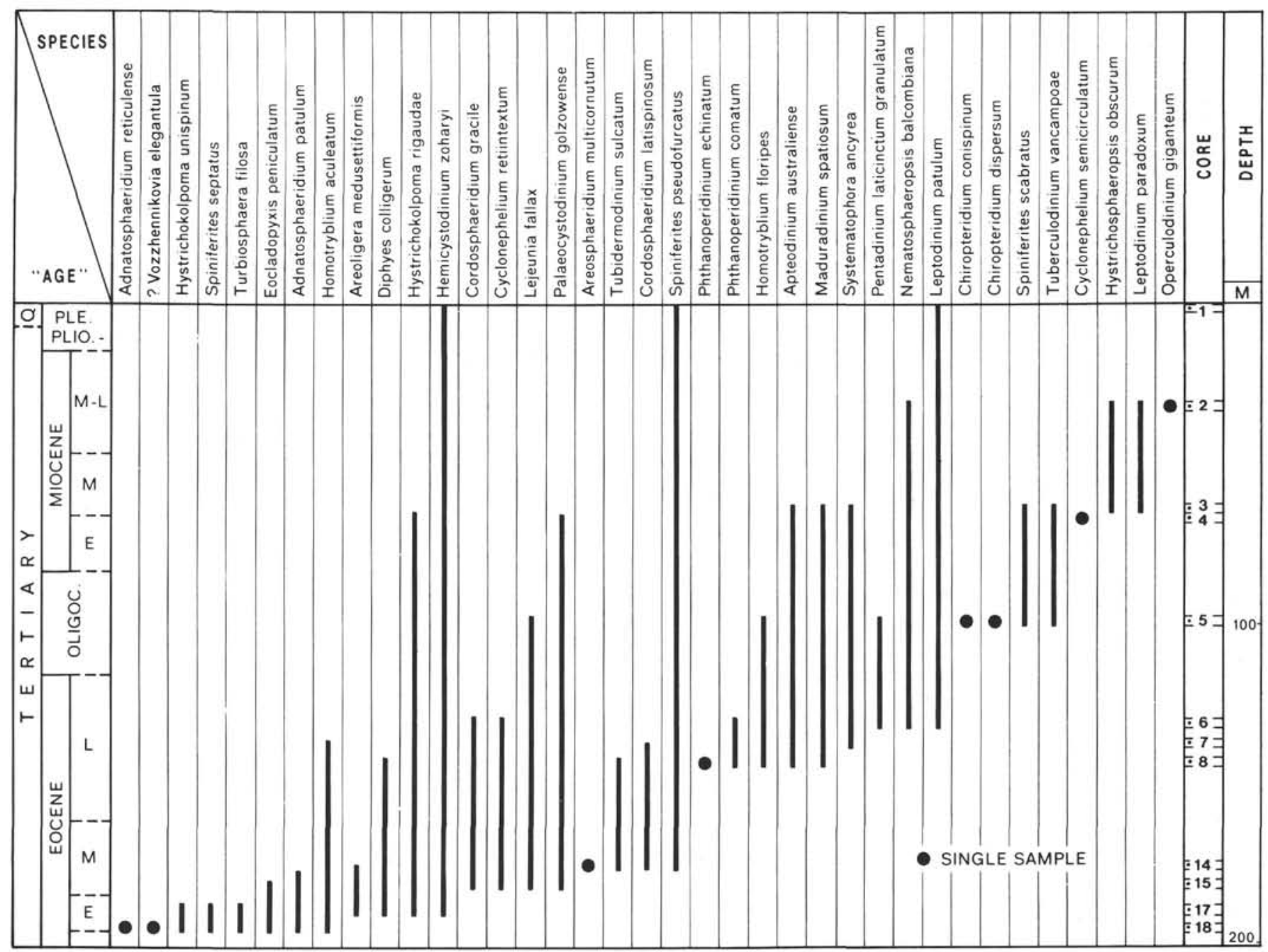

Figure 5. Stratigraphic ranges of selected dinocysts in the Cenozoic of DSDP Site 370. 
patulum and $A$. multicornutum have overlapping ranges only in the middle Eocene. This confirms the middle Eocene age for Cores 370-15 and 370-14.

The late Eocene sediments in Cores 370-8 through 370-6 (473.5-426 m) correlate with the coeval sediments in the DSDP Sites 1-6 and to the Scotian Shelf and Grand Banks. Species restricted to this horizon are Deflandrea spinulosa Alberti, Hemiplacophora semilunifera Cookson and Eisenack, Hystrichosphaeropsis ovum Deflandre, Phthanoperidinium comatum (Morgenroth) Eisenack and Kjellström, P. echinatum Eaton, and Schematophora speciosa Deflandre and Cookson. Species appearing for the first time are Apteodinium australiense (Deflandre and Cookson) comb. nov., Homotryblium floripes (Deflandre and Cookson) Stover, Lejeunia spatiosa Morgenroth, Nematosphaeropsis balcombiana Deflandre and Cookson, Pentadinium laticinctum granulatum Gocht, and Systematophora ancyrea Cookson and Eisenack. Species last occurring include Cordosphaeridium gracile (Eisenack) Davey and Williams, Diphyes colligerum, and Homotryblium aculeatum sp. nov.

Deflandrea spinulosa has a range of late Eocene to Oligocene on the Scotian Shelf-Grand Banks. Hemiplacophora semilunifera and Schematophora speciosa are restricted to the late Eocene in Sites 1 through 6, offshore Florida. In these same holes, Homotryblium floripes and Apteodinium australiense are first recorded from the late Eocene (personal observation). Diphyes colligerum is the late Eocene zonal index species in the Scotian Shelf-Grand Banks wells, last appearing at the same time as Cordosphaeridium gracile. The presence of the above species in the same samples is strong evidence for a late Eocene age.

The Oligocene assemblage in Core 370-5 (331-321.5 m) continues to show affinities to the Oligocene assemblages in DSDP Sites 1-6 and the Scotian ShelfGrand Banks wells. The middle to late Oligocene zonal species in the Scotian Shelf-Grand Banks wells, Chiropteridium dispersum Gocht is common in the single sample from Core 370-5. Also present are Chiropteridium conispinum sp. nov., Pentadinium laticinctum Gerlach, and Tuberculodinium vancampoae. These species overlap in the Oligocene only, in DSDP Sites 1 through 6 and the Scotian Shelf-Grand Banks wells. Several species last appearing in Core 370-5 of 367 meters range into the Miocene elsewhere. These include Cannosphaeropsis sp. A Williams and Brideaux (1975), Cordosphaeridium cantharellum (Brosius) Gocht, Lejeunia fallax Morgenroth, Pentadinium laticinctum and Polysphaeridium pastielsi Davey and Williams.

The Neogene dinocyst assemblages from Site 370 exhibit marked differences to the coeval sediments in the Scotian Shelf-Grand Banks wells, especially in the Plio-Pleistocene. Comparable assemblages are however present in DSDP Sites 1 through 6 and the Pleistocene cores recovered from the Caribbean and described by Wall (1967). Provincialism of dinocyst assemblages seems to be increasingly prevalent within the Neogene.

Early Miocene sediments are recognized between 226.5-217 meters (Core 370-4). Species appearing for the last time include Cyclonephelium semicirculatum Morgenroth, Cyclopsiella elliptica Drugg and Loeblich and Gonyaulacysta giuseppei (Morgenroth) Sarjeant. C. semicirculatum and $C$. elliptica were both originally described from the Oligocene by Morgenroth (1966b). and Drugg and Loeblich (1967) respectively. $G$. giuseppei has a known range of early Eocene-early Miocene. The postulated early Miocene age for this sample is confirmed by the foraminiferal data (this report).

The dinocyst assemblages in Core 370-3 (217-207.5 $\mathrm{m})$ show marked similarities to those in DSDP Sites 1 through 6 and the Scotian Shelf-Grand Banks wells. Apteodinium australiense, Lejeunia spatiosa, and Systematophora ancyrea are present for the last time, while Hystrichosphaeropsis obscurum Habib and Leptodinium paradoxum Wall appear. Williams and Brideaux (1975) extend Apteodinium australiense (as Apteodinium sp. Gocht, 1969) into the late Miocene. Williams (1975) restricted $H$. obscurum to the middle to late Miocene and recorded Systematophora ancyrea for the last time from the middle Miocene. The presence of these two species in the same sample is taken to indicate a middle Miocene age.

The interval 112.5-103 meters (Core 370-2) contains Hystrichosphaeropsis obscurum together with Leptodinium paradoxum, L. patulum Wall, and Pterodinium circumsutum Morgenroth. P. circumsutum according to Drugg and Stover (1975) has a known stratigraphic range of Oligocene to late Miocene. In DSDP Sites 1 through 6 , however, it ranges into the Pliocene. The presence of Hystrichosphaeropsis obscurum is the basis for the middle to late Miocene age determination.

Plio-Pleistocene sediments are recognized in Core $370-1(8-0 \mathrm{~m})$. The dinocyst assemblage compares closely with that described by Wall (1967) from the Caribbean. All the species present were also noted by Wall. These include Hemicystodinium zoharyi which is not present in post middle Miocene sediments in the Scotian Shelf-Grand Banks wells and Operculodinium centrocarpum (Deflandre and Cookson) Wall which is common in the Tertiary of the Scotian Shelf-Grand Banks wells, but does not extend above the Miocene. The Core 370-1 assemblage also shows a marked similarity to that in DSDP Sites 1-6. Provincialism is presumably responsible for the differences between the Scotian Shelf-Grand Banks on the one hand and the DSDP Sites 1-6, 267, and the Caribbean on the other hand in the Plio-Pleistocene.

\section{Conclusions}

Lower Cretaceous and Tertiary sediments predominate at Site 370 . The oldest, dated palynologically, are Valanginian. These are overlain by a more or less complete Hauterivian-Cenomanian sequence. The total observed thickness of the lower Cretaceous is 418 meters, overlain by approximately 85 meters of Cenomanian sediments. There is a gap between the highest Cenomanian sample at 673 meters and the lowest lower Eocene sample at 644.5 meters. Foraminiferal control indicates that the Cenomanian is immediately overlain by lower Paleocene, although 
there is a distance of 10 meters between the dated sediments. Palynological control within the Tertiary is good, but the boundaries are speculative because of the infrequent coring. Eocene through Plio-Pleistocene sediments have been recognized and compared with coeval assemblages from elsewhere. As in the Cretaceous, the Paleogene assemblages can be satisfactorily correlated with the Scotian Shelf-Grand Banks zones as formally proposed by Williams (1975). Increasing provincialism in the Neogene necessitates comparison with the more closely similar assemblages from DSDP Sites 1 through 6, offshore Florida. Recovery of dinocysts from all samples has been excellent; spores and pollen have been rare. The high degree of reworked material is discussed in the following section.

\section{Reworked Dinocysts in the Samples from Site 370}

Reworked dinocyst species have been recognized in 18 of the samples examined from Site 370 and attain a peak in the Eocene. Their distribution and age are shown in Figure 6. The differentiation of reworked and indigenous material can pose severe problems if they are either long-ranging species or if they are not far removed stratigraphically. Fortunately the present investigation was greatly facilitated by the ability of reworked and indigenous species to take stain differentially. This technique, which has been presented in detail by Stanley $(1965,1966)$, is not a foolproof method, but can be instrumental in separating indigenous and reworked material, as at Site $\mathbf{3 7 0 .}$

The reworked species fall into distinct categories. The Valanginian-Hauterivian samples, Cores 370-50 to 370-34 extending from 1167-872.5 meters, contain reworked species which have a known range of Callovian to Portlandian. The differential staining technique does not work with these samples. The percentage of reworked specimens is below $10 \%$. Reworking in the Barremian-Cenomanian, from Cores 370-32 to 37020 or $844-673$ meters is minimal with only a few specimens of late Jurassic-early Cretaceous age apparently being reworked. There is, however, considerable difficulty in interpreting what is reworked since most of the species, indigenous or reworked, do not stain.

Recognition of reworked specimens is greatly simplified in the Eocene which extends from Cores 37018 to $370-6$ or 644.5-426 meters. The indigenous species readily accept the stain Safranin "O"; the reworked species do not stain and therefore retain their body color which may vary from almost colorless to dark brown. Although some of the reworked species present in the Eocene range throughout the Cretaceous, collation of the data indicates that the source was Campanian to Paleocene. Species with a MaestrichtianPaleocene range are particularly abundant in the lower cores. The percentage of reworked specimens in the total dinocyst count may be as high as $25 \%$ to $30 \%$. The source area may lie to the east or be local and represent sediments deposited and subsequently removed in post Cenomanian-pre Paleocene time. This second possibility, however, is not supported by the reworked species, most of which tend to be concentrated in inner neritic environments. Jansa (this volume) includes this interval in his Unit 3, a nannofossil-radiolarian bearing calcareous silty clay sequence, with porcellanite and chert, and silt, sand, and gravel beds. Turbidites and slump deposits occur in Cores 370-18 through 370-12 (644.5-540 m).

The reworked late Cretaceous species are also present in the Oligocene (Core 370-5, 331-321.5 m) and early Miocene (Core 370-4, 226.5-217 m). One species of Barremian-Cenomanian age is reworked into the late Miocene (112.5-103 m).

The age of the reworked material shows a marked change in the single Pleistocene Core 370-1, from 8-0 meters. Only Tertiary species are present, ranging in age from early Eocene to middle Miocene. There is also a marked drop in the percentage of reworked material which is approximately $10 \%$.

Three reworked zones are therefore recognizable. The oldest, restricted to the early Cretaceous, includes several species which are restricted to the Jurassic. These do not stain differentially to the indigenous species so that it is possible that several longer ranging species which are also reworked in the Early Cretaceous, have been overlooked. The second zone, present in the Eocene to Miocene sediments is composed of species whose overlapping ranges suggest a Senonian-Paleocene age. These do not stain whereas the indigenous Tertiary species stain pink to red. Differentiation of the two categories is therefore relatively simple. Zone three is restricted to the single Pleistocene sample and contains only species of an original Tertiary age. The reworked species of Zone 3 show a variable acceptance to stain so that differentiation by this method alone is very difficult. The absence of pre Tertiary species in the Pleistocene contrasts with their high relative abundances in the Eocene.

\section{SYSTEMATIC DESCRIPTIONS}

Division PYRRHOPHYTA Pascher, 1914

Class DINOPHYCEAE Fritsch, 1929

Order PERIDINIALES Haeckel, 1894

Apteodinium Eisenack, 1958

Apteodinium australiense (Deflandre and Cookson, 1955) comb. nov., pl. 1 , fig. 3 .

1955 Gymnodinium australiense Deflandre and Cookson, p. 248, pl. 5, fig. 1.

1967 Scriniodinium australiense (Deflandre and Cookson) Eisenack, p. 195.

1969 Apteodinium sp. Gocht, p. 30, pl. 6, fig. 6.

Remarks: This species is abundant in samples from Site 367 and the Miocene of the Scotian Shelf and Grand Banks. It has a precingular archeopyle resulting from the loss of the third precingular paraplate and a distinct paracingulum. Further evidence of paratabulation is usually lacking. The morphology of this species, which is proximate, forbids its retention in Scriniodinium Klement.

Genus CHIROPTERIDIUM Gocht, 1960

Chiropteridium conispinum sp. nov. (Plate 2, Figures 1-6)

Diagnosis: Chorate cyst with subcircular ambitus. Phragma microreticulate, lumina very irregular in size and shape. On the 


\begin{tabular}{|c|c|c|c|c|c|c|c|c|c|}
\hline \multicolumn{3}{|c|}{$\begin{array}{l}\text { GEOCHRONOLOGICAL } \\
\text { SUBDIVISIONS }\end{array}$} & \multirow[t]{2}{*}{$\begin{array}{c}\text { ZONE } \\
\text { (after Williams, 1975) }\end{array}$} & \multirow{2}{*}{\begin{tabular}{l}
\multicolumn{1}{c}{ REW ORKED SPECIES } \\
Lejunia fallax \\
Selenopemphix nephroides \\
Vozzhennikovia elegangula \\
Tanyosphaeridium sp. A. Will. and Brid.
\end{tabular}} & \multirow{2}{*}{$\begin{array}{l}\text { KNOWN STRATIGRAPHIC } \\
\text { RANGE } \\
\text { M. Eocene-M. Miocene } \\
\text { Oligocene } \\
\text { Early Eocene } \\
\text { L. Eocene-M. Miocene } \\
\end{array}$} & \multirow{2}{*}{\begin{tabular}{|c|}
$\begin{array}{c}\text { IN TERVAL } \\
(\mathrm{cm})\end{array}$ \\
$80-82$
\end{tabular}} & \multirow{2}{*}{\begin{tabular}{|c|} 
SECTION \\
3
\end{tabular}} & \multirow{2}{*}{\begin{tabular}{|c|} 
CORE \\
1 \\
\end{tabular}} & \multirow{2}{*}{$\begin{array}{c}\text { DEPTH } \\
\text { CORE (m) } \\
0.8\end{array}$} \\
\hline \multirow{12}{*}{ 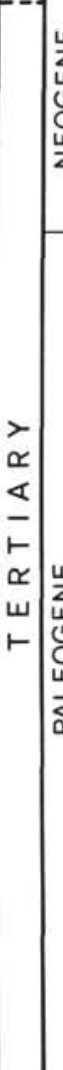 } & $\begin{array}{l}\text { PLEISTOCENE } \\
\text { PLIOCENE }\end{array}$ & & & & & & & & \\
\hline & & $\mathrm{M}$ & & Cleistosphaeridium polypes & Barremian-Cenomanian & $133-135$ & 1 & 2 & $103-112.5$ \\
\hline & MIOCENE & $M$ & & & & $78-80$ & 2 & 3 & $207.5-217$ \\
\hline & & $\mathrm{E}$ & & $\begin{array}{l}\text { Isabelia cooksoniae } \\
\text { Oligosphaeridium complex }\end{array}$ & $\begin{array}{l}\text { Santonian-E. Paleocene } \\
\text { Valanginian-E. Paleocene }\end{array}$ & $61-63$ & 3 & 4 & $217-226.5$ \\
\hline & OLIGO & & Chiropteridium dispersum & $\begin{array}{l}\text { Cordosphaeridium gracile } \\
\text { Isabelia cretacea }\end{array}$ & $\begin{array}{l}\text { Danian-L. Eocene } \\
\text { Maastrichtian-E. Paleocene }\end{array}$ & $108-110$ & 1 & 5 & $321.5-331$ \\
\hline & \multirow{7}{*}{ EOCENE } & \multirow{3}{*}{ L } & \multirow{3}{*}{ Diphjes colligerum } & & & $68-69$ & 1 & 6 & $426-435.5$ \\
\hline & & & & Odontochitina costata & Albian-Campanian & $88-90$ & 2 & 7 & $445-454.5$ \\
\hline & & & & $\begin{array}{l}\text { Isabelia belfastensis } \\
\text { Isabelia cooksoniae }\end{array}$ & $\begin{array}{l}\text { Santonian-Maastrichtian } \\
\text { Santonian-E. Paleocene }\end{array}$ & $60-62$ & 2 & 8 & $464-473.5$ \\
\hline & & \multirow[t]{2}{*}{ M } & \multirow[t]{2}{*}{ Adnatosphaeridium reticulense } & $\begin{array}{l}\text { Cyclonephelium distinctum } \\
\text { Deflandrea speciosa } \\
\text { Isabelia cooksoniae } \\
\text { Odontochitina costata } \\
\text { Palaeohystrichophora infusorioides } \\
\text { Trichodinium castaneum } \\
\end{array}$ & $\begin{array}{l}\text { Berriasian-Campanian } \\
\text { Paleocene } \\
\text { Santonian-E. Paleocene } \\
\text { Albian-Campanian } \\
\text { L. Albian-Campanian } \\
\text { Hauterivian-Campanian }\end{array}$ & $98-100$ & 2 & 14 & $568.5-578$ \\
\hline & & & & $\begin{array}{l}\text { Deflandrea speciosa } \\
\text { Isabelia belfastensis } \\
\text { Isabelia cooksoniae } \\
\text { Isabelia cretacea } \\
\text { Odontochitina operculata } \\
\text { Palaeoperidinium pyrophorum }\end{array}$ & $\begin{array}{l}\text { Paleocene } \\
\text { Santonian-Maastrichtian } \\
\text { Santonian-E. Paleocene } \\
\text { Maastrichtian-E.Paleocene? } \\
\text { Hauterivian-Campanian } \\
\text { Maastrichtian-E. Paleocene }\end{array}$ & $130-132$ & 3 & 15 & $587.5-597$ \\
\hline & & \multirow{2}{*}{$E$} & \multirow{2}{*}{ Areoligera senonensis } & $\begin{array}{l}\text { Isabelia cooksoniae } \\
\text { Isabelia cretacea } \\
\text { Palaeocystodinium benjaminii } \\
\text { Tanyosphaeridium magdalium }\end{array}$ & $\begin{array}{l}\text { Santonian-E. Paleocene } \\
\text { Maastrichtian-E. Paleocene? } \\
\text { Maastrichtian-L. Paleocene } \\
\text { Maastrichtian-E. Paleocene }\end{array}$ & $98-100$ & 1 & 17 & $616-625.5$ \\
\hline & & & & $\begin{array}{l}\text { Deflandrea diebeli } \\
\text { Dinogymnium acuminatum } \\
\text { Isabelia cretacea } \\
\text { Oligosphaeridium complex }\end{array}$ & $\begin{array}{l}\text { Maastrichtian-E. Paleocene } \\
\text { ?Coniacian-Maastrichtian } \\
\text { Maastrichtian-E. Paleocene } \\
\text { Valanginian-E. Paleocene }\end{array}$ & $54-56$ & 2 & 18 & $635-644.5$ \\
\hline
\end{tabular}

Figure 6. Dinocyst species identified as reworked in DSDP Site 370. 


\begin{tabular}{|c|c|c|c|c|c|c|c|c|}
\hline \multirow{8}{*}{ 岁 } & \multirow{8}{*}{ CENOMANIAN } & \multirow{8}{*}{ Cleistosphaeridium polyes } & & & $78-80$ & 1 & \multirow{2}{*}{20} & \multirow{2}{*}{$673-682.5$} \\
\hline & & & & & $68-70$ & 3 & & \\
\hline & & & & & $28-30$ & 1 & \multirow{2}{*}{21} & \multirow{2}{*}{$682.5-692$} \\
\hline & & & & & $68-70$ & 2 & & \\
\hline & & & Tenua hystrix & Kimmeridgian-Aptian & $79-81$ & 1 & 22 & $692-701.5$ \\
\hline & & & & & $78-80$ & 3 & 23 & $701.5-711$ \\
\hline & & & Tenua hystrix & Kimmeridgian-Aptian & $78-80$ & 3 & 24 & $711-720.5$ \\
\hline & & & & & $78-80$ & 2 & 26 & $730-739.5$ \\
\hline \multirow{16}{*}{ 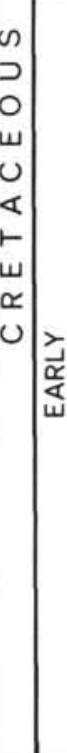 } & \multirow{3}{*}{ ALBIAN } & \multirow{3}{*}{ Spinidinium ct. vestitum } & & & $88-90$ & 1 & \multirow{2}{*}{27} & \multirow{2}{*}{$749-758.5$} \\
\hline & & & & & $48-50$ & 3 & & \\
\hline & & & & & $68-70$ & 2 & 28 & $768-777.5$ \\
\hline & \multirow{2}{*}{ APTIAN } & \multirow{2}{*}{$\begin{array}{l}\text { Systematophora schindewolfi } \\
\text { Subtilisphaera perlucida }\end{array}$} & & & $58-60$ & 4 & 30 & $806-815.5$ \\
\hline & & & Spiniferites "duplifurcatus" & Berriasian-Valanginian & $68-70$ & 3 & 31 & $825-834.5$ \\
\hline & \multirow{5}{*}{ HAUTERIVIAN } & Tenua anaphrissa & & & $115-117$ & 1 & 32 & $834.5-844$ \\
\hline & & \multirow{4}{*}{ Ctenidodinium elegantulum } & & & $78-80$ & 3 & 34 & $872.5-882$ \\
\hline & & & Gonyaulacysta ambigua & Oxfordian-Kimmeridgian & $91-93$ & 1 & 35 & $882-891.5$ \\
\hline & & & & & $113-115$ & 4 & 38 & $939-948.5$ \\
\hline & & & $\begin{array}{l}\text { Ctenidodinium culmulum } \\
\text { Gen. et sp. } 2 \text { Gocht }\end{array}$ & $\begin{array}{l}\text { L. Kimmeridgian-Portlandian } \\
\text { Bathonian-Oxfordian }\end{array}$ & $54-56$ & 2 & 39 & $948.5-958$ \\
\hline & \multirow{6}{*}{ VALANGINIAN } & \multirow{6}{*}{ Phoberocysta neocomica } & & & $115-117$ & 1 & 41 & $986.5-996$ \\
\hline & & & Gonyaulacysta jurassica & Callovian-E. Kimmeridgian & $80-82$ & 1 & \multirow{2}{*}{44} & \multirow{2}{*}{$1043.5-1053$} \\
\hline & & & & & $54-56$ & 3 & & \\
\hline & & & Gonyaulacysta jurassica & Callovian- E. Kimmeridgian & $108-110$ & 1 & 45 & $1062.5-1072$ \\
\hline & & & & & $70-72$ & 2 & 48 & $1119.5-1129$ \\
\hline & & & Systematophora fasciculigera & Oxfordian-Tithonian & $85-87$ & 1 & 50 & $1157.5-1137$ \\
\hline
\end{tabular}

Figure 6. (Continued). 
ventral surface linear membranes originating on the first and fifth precingular paraplates, respectively, run towards the antapex.

Membranous processes, generally restricted to the dorsal surface, are proximally conical or subconical and distally may branch into slender tubules. The processes are nontabular. Archeopyle apical, tetratabular. Parasulcal notch visible. Paratabulation indeterminate other than 1 pra, 4', 6".

Dimensions: Cyst width, $64-81 \mu \mathrm{m}$, length (less operculum) $59-70$ $\mu \mathrm{m}$. Processes up to $20 \mu \mathrm{m}$, linear membrane rarely exceeding $10 \mu \mathrm{m}$ in height. Number of specimens measured, 6.

Holotype: GSC No. 47855; P8177-01, $3.4 \times 102.4$. Diameter width $87 \mu \mathrm{m}$, length $64 \mu \mathrm{m}$. Processes up to $20 \mu \mathrm{m}$. Oligocene, Site 370 .

Description: The ventral surface of the cyst always bears two membranes with their entire margins running apically antapically. These originate on the apical paraplates in one specimen. In specimens lacking an operculum, they always originate towards the midline on paraplates $1^{\prime \prime}$ and $5^{\prime \prime}$, respectively, and extend to the antapex, where they form two distinct antapical projections. These membranes may have a single process along their length, at which point there is a change in direction, and antapically. Occasionally a third membrane runs laterally across the dorsal surface in the vicinity of the postcingular antapical paraplate boundaries. The processes, generally restricted to the operculum and the dorsal surface are membranous, proximally conical to subconical and sometimes open on one side, in effect forming a soleate structure. In some specimens they are ribbed. The processes rarely exceed 12 in number and apparently do not relate to paratabulation. In the vicinity of the archeopyle margin they appear to be located on the parasutures between adjacent precingular paraplates. Distally the processes may be acuminate closed, or produced into slender tubules up to $12 \mu \mathrm{m}$ in length. One operculum possesses five such processes, united to each other by membranes. Four of these processes are peripherally located on paraplates $\mathrm{I}^{\prime}$ through $4^{\prime}$. The fifth is centrally located and is presumably a preapical. Of the precingulars, 6 " is always devoid of processes. The other precingulars, excluding $1^{\prime \prime}$ and $5^{\prime \prime}$, appear to bear processes suturally. Some specimens show lateral process alignment in what is presumably the vicinity of the paracingulum.

Remarks: Only one species of ('hiropteridium, C. aspinatum (Gerlach) Brosius, bears a superficial resemblance to $C$. conispinum. C. aspinatum does not, however, possess processes and the apicallyantapically aligned membranes when examined under the scanning electron microscope are seen to form closed structures with one wall on the lateral dorsal surface, and one on the lateral ventral surface.

\section{Genus HOMOTRYBLIUM Davey and Williams, 1966b}

\section{Homotryblium aculeatum sp. nov.}

(Plate 4, Figures 5, 6, 8, 9)

Diagnosis: Chorate cyst with spherical to slightly ellipsoidal shape. Phragma composed of thin laevigate endophragm and thin scabrate periphragm, from which arise the processes. There is one intratabular process per paraplate, apart from a single, slender, solid acuminate or bifid process, whose location is variable on the hypocyst. Processes are tubiform, slender open distally with an aculeate or secate margin. Aculei and secae may be simple or branched and are commonly recurved. Process formula 4', 6", $6 \mathrm{c}, 5^{\prime \prime}$ ', Ip, 1" ", 2s. Paracingulum delineated by six processes, parasulcus indicated by anterior sulcal paraplate and two processes. Archeopyle epicystal formed from the loss of the four apicals and six precingulars.

Dimensions: Cyst diameter 40-53 $\mu \mathrm{m}$. Processes, length $19-25 \mu \mathrm{m}$, width 1 to $3 \mu \mathrm{m}$. Aculei and secae up to $5 \mu \mathrm{m}$ in length. Number of specimens measured, 8.

Holotype: GSC No. 47873; P8182-01, $6.0 \times 109.4$. Diameter 44 by $50 \mu \mathrm{m}$. Process length $19-22 \mu \mathrm{m}$. Middle Eocene, Site 370 .

Description: The process formula of Homotryblium aculeatum indicates its gonyaulacacean affinities although it does not reveal the presence of a sixth postcingular paraplate. The paraplates of the eipicyst may remain attached or there may be separation of the apicals from the precingulars or within the precingulars. The hypocystal paraplates never show separation. the processes are slender, particularly the anterior sulcal and $6^{\prime \prime}$. Some processes proximally exhibit the floral pattern as seen in Homotryblium floripes (Deflandre and Cookson) Stover. Distally the recurved aculei or secae, which can number up to 13 on an individual process, may be simple or bifurcate. Occasionally they exhibit first- and second-order bifurcations as in Spiniferites ramosus (Ehrenberg) Loeblich and Loeblich. The small adventitious process located on the hypocyst is solid, distally acuminate or bifid. The number of processes appears to be constant, there being 10 on the epicyst and 15 on the hypocyst.

Remarks: Six species of Homotryblium have been described in the literature. These are $H$. bifurcatum Caro, $H$. floripes (Deflandre and Cookson) Stover, $H$. pallidum Davey and Williams, H. plectilum Drugg and Loeblich, $H$. tasmaniense Cookson and Eisenack, and $H$. tenuispinosum Davey and Williams. Only $H$. pallidum. $H$. tasmaniense, and $H$. tenuispinosum have simple tubiform processes. open distally. None of these, however, possess the long, recurved. branched aculei or secae as found in $H$. aculeatum.

\section{Genus OLIGOSPHAERIDIUM Davey and Williams, 1966b}

\section{Oligosphaeridium dividuum sp. nov.} (Plate 5, Figure 8)

Diagnosis: Chorate cyst with subspherical, or ellipsoidal shape. Phragma laevigate, scabrate, or finely rugulate. Processes formed from the periphragm which may be up to $1 \mu \mathrm{m}$ thick in the process walls. Processes intratabular, commonly one per paraplate, sometimes two or three showing some variation in size according to location. Processes are buccinate sometimes simple but commonly branched. They are generally open distally with simple or branched aculei or secae up to $25 \mu \mathrm{m}$ in length. Aculei and secae may be patulate, orthogonal, or recurved. They are sometimes united along their length. Process formula 4", 6" 5"', Ip, 1'"', Is. Paracingulum devoid of processes. Parasulcus containing one slender process. Archeopyle apical tetratabular. Operculum free.

Dimensions: Cyst diameter 40-60 $\mu \mathrm{m}$. Processes, length $23-43 \mu \mathrm{m}$. width 1-7 $\mu \mathrm{m}$. Number of specimens measured, 6 .

Holotype: GSC No, 47891; P8205-01, $5.6 \times 117.0$. Diameter 40 by $46 \mu \mathrm{m}$. Process length $27-43 \mu \mathrm{m}$. Valanginian, Site 370 .

Description: All specimens of Oligosphaeridium dividuum possess simple and branched processes distally produced into aculei or secae. The branching can occur anywhere along the process length: occasionally it occurs proximally so that an individual paraplate bears two or three processes. The aculei and secae may be simple or branched, occasionally united along their length or remain free. Distally they may be further branched acuminate, commonly bulbous, or bifid. Some processes have very short stems with the aculei extending almost to the base of the process. The aculei are sometimes recurved but may be orthogonal or patulate. There are up to six aculei per process. Occasional processes appear solid. Several are closed distally. The posterior intercalary and sulcal processes tend to be smaller than the others. The archeopyle frequently has accessory sutures separating the precingular paraplates.

Remarks: Two species of Oligosphaeridium, $O$. asterigerum (Gocht) Davey and Williams, and $O$. complex (White) Davey and Williams bear a superficial resemblance to $O$. dividuum. Neither of these species possess branched processes or more than one process per paraplate however. The aculei in $O$. asterigerum and $O$. complex are simple or occasionally bifid, but never attain the relative length of the aculei and secae in $O$. dividuum.

\section{Oligosphaeridium ef. complex}

(Plate 5, Figures 7, 10, 11)

Description: Oligosphaeridium cf. complex has tubiform to buccinate processes produced distally into very long aculei or secae. The processes are intratabular, one per paraplate. The aculei are generally bulbous distally. The secae are bifid or oblate. Both may be up to $20 \mu \mathrm{m}$ in length. Each process may possess up to 12 aculei which are usually patulate but may be orthogonal. The processes are very rarely branched. The process formula is $4^{\prime}, 6^{\prime \prime}, 5^{\prime \prime \prime}, 1 \mathrm{p}, 1^{\prime \prime \prime \prime}$, Is. The posterior intercalary and sulcal processes are smaller than the others.

Dimensions: Cyst diameter 43-61 $\mu \mathrm{m}$. Processes, length $15-51 \mu \mathrm{m}$, width up to $7 \mu \mathrm{m}$. Number of specimens measured, 6 .

\section{Genus VOZZHENNIKOVIA Lentin and Williams, 1976}

?Vozzhennikovia elegantula sp. nov.

(Plate 7, Figures 7, 9)

Diagnosis: The pericyst ambitus is ovoidal to pentagonal, widest in precingular region. Apex occasionally rounded, more commonly 
produced into a short apical horn which distally may be acuminate or oblate. Antapex flattened or with slight asymmetry, there being a weak left antapical lobe. Epipericyst and hypopericyst more or less equal in size. Length:breadth ratio about 1 . Compression very slight.

An endocyst has not been observed. Periphragm laevigate with parasutural processes which are simple, slender, distally oblate or bulbous. The processes may be isolated or united proximally by a membrane. The paratabulation is presumably peridinioid since there is a hexa $2 \mathrm{a}$ intercalary paraplate. Pericingulum helicoidal, heptapentapartite with parasutural processes. Perisulcus indented, largely restricted to the hypocyst and widening antapically. Archeopyle hexa, intercalary, resulting from the partial or complete detachment of the second anterior intercalary paraplate $2 \mathrm{a}$. Operculum often remains attached along parasuture $\mathrm{H} 4$.

Dimensions: Pericyst length 50-52 $\mu \mathrm{m}$, breadth $45-56 \mu \mathrm{m}$. Processes, length 2-10 $\mu \mathrm{m}$. In apical view lateral width $45-50 \mu \mathrm{m}$. Number of specimens measured, 6 .

Holotype: GSC No. 47910, P8182-01. $10.2 \times$ 101.7. Pericyst length $51 \mu \mathrm{m}$, breadth $56 \mu \mathrm{m}$. Process length $2-7 \mu \mathrm{m}$. Middle Eocene, Site 370 .

Description: ?Vozzhennikovia elegantula has a distinctly peridinioid ambitus, but lacks the prominent antapical horns which characterize several peridinioid genera. The parasutural processes are hollow throughout or for half to two-thirds of their length, terminating in a slender solid tip. The cingular processes tend to be shorter than the others. Delineation of the paratabulation is difficult when the processes are not united proximally. The archeopyle is hexa with the operculum often remaining attached proximally.

Remarks: The genus Vozzhennikovia was erected by Lentin and Williams $(1976)^{\circ}$ to include peridinioid taxa with processes which are nontabular. Six species were included in the genus Vozzhennikovia by these authors. Only two, ? $V$. extensa (Stover) Lentin and Williams and ? $V$. filigrana (Benedek) Lentin and Williams, are known to possess a broad hexa $2 \mathrm{a}$ archeopyle, but both have nontabular processes. V. elegantula is questionably placed in Vozzhennikovia because of its parasutural processes. It cannot be included in the genus Wilsonidium Lentin and Williams which has parasutural ornamentation because of the possession by that genus of a quadra $2 \mathrm{a}$ archeopyle. The only other comparable genus, Sumatradinium Lentin and Williams, lacks an apical horn.

The coordinates given are those for a Zeiss Photomicroscope Il. The vertical reading precedes the horizontal. The repository for all type material is the Geological Survey of Canada, Ottawa.

\section{REFERENCES}

Alberti, G., 1961. Zur Kenntnis Mesozoischer und Alttertiärer Dinoflagellaten und Hystrichosphaerideen von Nord- und Mitteldeutschland sowie einigen anderen Europäischen Gebieten: Palaeontographica, v. 116, p. 158.

Clarke, R.F.A. and Verdier, J.-P., 1967. An investigation of microplankton assemblages from the Chalk of the Isle of Wight, England: Verh. Kon. Nederl. Akad. Wetensch., Afd. Natuurk., Eerste Reeks, v. 24, p. 1-96.

Cookson, I.C. and Hughes, N.F., 1964. Microplankton from the Cambridge Greensand (mid-Cretaceous): Palaeontology, v. 7, p. 37-59.

Davey, R.J., 1970. Non-calcareous microplankton from the Cenomanian of England, northern France and North America, Part II; British Mus. Nat. Hist. Bull. (Geol), v. 18 , p. $333-397$.

Davey, R.J. and Verdier, J.-P., 1971. An investigation of microplankton assemblages from the Albian of the Paris Basin: Verh. Kon. Nederl, Akad. Wetensch., Afd. Natuurk., Eerste Reeks, v. 26, p. 1-58.

1973. An investigation of microplankton assemblages from latest Albian (Vraconian) sediments: Rev. Esp. Micropaleontol., v. 5, p. 173-212.

1974. Dinoflagellate cysts from the Aptian type sections at Gargas and La Bedoule, France: Palaeontology, v. 17 , p. 623-653.

Deflandre, G. and Cookson, I.C., 1955. Fossil microplankton from Australian Late Mesozoic and Tertiary sediments: Australian J. Mar. Freshwater Res., v. 6, p. 242-313.

Drugg, W.S. and Loeblich, A.R., Jr., 1967. Some Eocene and Oligocene phytoplankton from the Gulf Coast, U.S.A.: Tulane Stud. Geol., v. 5, p. 181-194.

Drugg, W.S. and Stover, L.E., 1975. Stratigraphic range charts of selected Cenozoic dinoflagellates. In Stratigraphic range charts of selected fossil dinoflagellates: Am. Assoc. Strat. Palynol. Contrib., Ser. 4, p. 73-76.

Eaton, G.L., 1971. A morphogenetic series of dinoflagellate cysts from the Bracklesham Beds of the Isle of Wight, Hampshire, England. In Farinacci, A. (Ed.), Second Plankt. Conf. Proc. Roma 1970: Rome (Tecnoscienza), v. 1 , p. $355-379$.

Eisenack, A., 1967. Katalog der fossilien Dinoflagellaten, Hystrichosphäeren und verwandten Mikrofossilien. Band I Dinoflagellaten. I Ergänzungslieferung: Stuttgart (E. Schweizerbart'sche Verlagsbuchhandlung).

Eisenack, A. and Cookson, I.C., 1960. Microplankton from Australian Lower Cretaceous sediments; Roy. Soc. Victoria Proc., v. 72, p. 1-11.

Gitmez, G.U. and Sarjeant, W.A.S., 1972. Dinoflagellate cysts and acritarchs from the Kimmeridgian (Upper Jurassic) of England, Scotland and France: British Mus. Nat. Hist. Bull. (Geol.), v. 21, p. 171-257.

Gocht, H., 1957. Mikroplankton aus dem nordwestdeutschen Neokom (Teil I): Palaontol. Z., v. 31, p. 163-185. 1959. Mikroplankton aus dem nordwestdeutschen Neokom (Teil II): Palaontol. Z., v. 33, p. 50-89.

1969. Formengemeinschaften Alttertiaren Mikroplanktons aus Bohrproben des Erdolfeldes Meckelfeld bei Hamburg: Palaeontographica, v. 126, p. 1-100.

Habib, D., 1972. Dinoflagellate stratigraphy Leg 11, Deep Sea Drilling Projects. In Hollister, C.D., Ewing, J.I., et al., Initial Reports of the Deep Sea Drilling Project, Volume 11: Washington (U.S. Government Printing Office), p. $367-425$.

Lentin, J.K. and Williams, G.L., 1976. A monograph of fossil peridinioid dinoflagellate cysts; Bedford Inst. Oceanogr. Rept. Ser./BI-R-75-16, p. 1-237.

Millioud, M.E., 1975. Ranges of selected Early Cretaceous dinoflagellates. In Stratigraphic range charts of selected fossil dinoflagellates: Am. Assoc. Strat. Palynol., Contrib., Ser. 4, p. 65-71.

Morgenroth, P., 1966a. Mikrofossilien und Konkretionen des nordwesteuropaischen Untereozäns: Palaeontographica, v. 119, p. $1-53$.

1966b. Neue in organischer Substanz erhaltene Mikrofossilien des Oligozäns: Neues Jahrb. Geol. Paläontol., Abh., v. 127, p. 1-12.

Norris, G., 1965. Archeopyle structures in Upper Jurassic dinoflagellates from southern England: New Zealand J. Geol. Geophys., v. 8, p. 792-806.

Sarjeant, W.A.S., 1975. Stratigraphic range charts: Triassic and Jurassic dinoflagellates. In Stratigraphic range charts of selected fossil dinoflagellates; Am. Assoc. Strat. Palynol., Contrib., Ser. 4, p. 51-63.

Singh, C., 1964. Microflora of the Lower Cretaceous Mannville Group, east-central Alberta: Res. Council Alberta, Bull. 15, 239 p.

, 1971. Lower Cretaceous microfloras of the Peace River area, northwestern Alberta: Res. Council Alberta, Bull. 28, v. 2, p. 301-542.

Stanley, E.A., 1965. Use of reworked pollen and spores for determining the Pleistocene-Recent and the IntraPleistocene boundaries: Nature, v. 206, p. 289-291.

1966. The application of palynology to oceanology with reference to the northwestern Atlantic: Deep-Sea Res., v. 13, p. 921-939. 
Wall, D., 1967. Fossil microplankton in deep-sea cores from the Caribbean Sea: Palaeontology, v. 10, p. 95-123.

Wall, D., and Dale, B., 1969. The "hystrichosphaerid" resting spore of the dinoflagellate Pyrodinium bahamense Plate, 1906: J. Phycol., v. 5, p. 140-149.

Williams, G.L., 1975. Dinoflagellate and spore stratigraphy of the Mesozoic-Cenozoic, offshore eastern Canada. In Offshore Geology of Eastern Canada: Geol Surv. Canada, Paper 74-30, v. 2, p. 107-161.
Williams, G.L. and Brideaux, W.W., 1975. Palynological analyses of Upper Mesozoic and Cenozoic rocks of the Grand Banks, Atlantic continental margin: Geol. Surv. Canada, Bull. 236, p. 1-162.

Williams, G.L. and Downie, C., 1966. The genus Hystrichokolpoma. In Davey, R.J., Downie, C., Sarjeant, W.A.S., and Williams, G.L. (Eds.), Studies on Mesozoic and Cainozoic dinoflagellate cysts: British Mus. Nat. Hist. Bull. (Geol.), Suppl. 3, p. 176-181. 


\section{PLATE 1}

Figure $1 \quad$ Veryhachium sp. Oligocene, Site 370. ×1000; GSC No. 47845 .

Figure $2 \quad$ Veryhachium sp. Oligocene, Site $370 . \times 800$; GSC No. 47846.

Figure 3 Apteodinium australiense (Deflandre and Cookson) comb. nov., late Eocene, Site 370. ×500; GSC No. 47847 .

Figure $4 \quad$ Aptea polymorpha Eisenack, Aptian. Site 370. $\times 800$; GSC No. 47848 .

Figure $5 \quad$ Aptea polymorpha Eisenack, Barremian, Site 370. $\times 800$; GSC No. 47849.

Figure 6 Areoligera medusettiformis (O. Wetzel) LejeuneCarpentier, early Eocene, Site $370 . \times 500 ; 47850$.

Figure 7 Cannosphaeropsis sp. A Williams and Brideaux, 1975, Oligocene, Site 370. $\times 800$; GSC No. 47851.

Figure 8 ?Adnatosphaeridium patulum Williams and Downie, middle Eocene, Site 370. ×500; GSC No. 47852 .

Figure 9 Concentricystes rubinus Rossignol, Plio-Pleistocene, Site 367. ×800; GSC No. 4853.

Figure 10 Ovoidinium scabrosum (Cookson and Hughes) Davey, basal Cenomanian, Site 370 . $\times 800$; GSC No. 47854 . 
PLATE 1
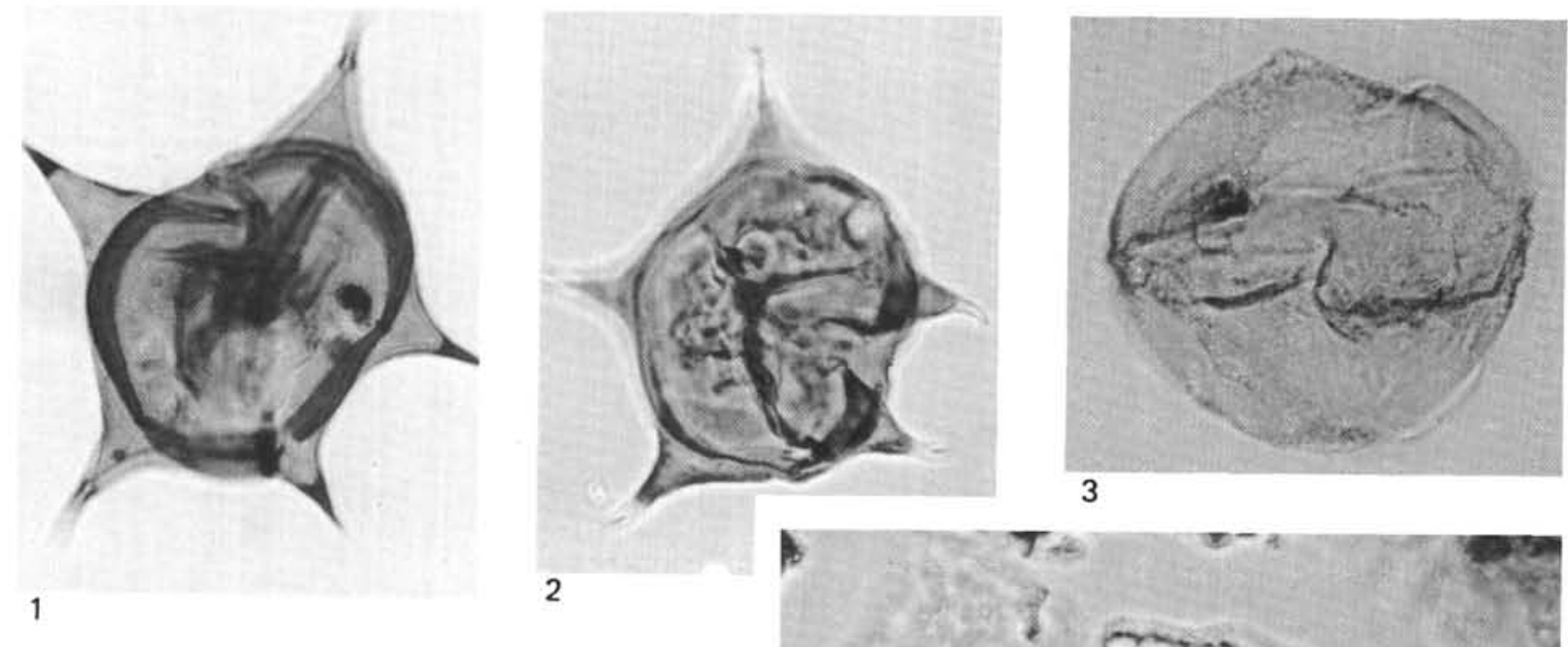

$$
1
$$

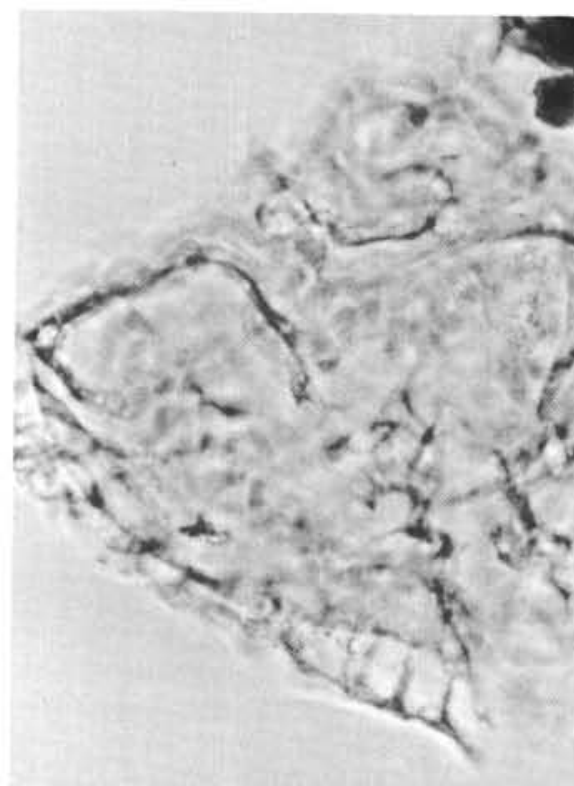

4

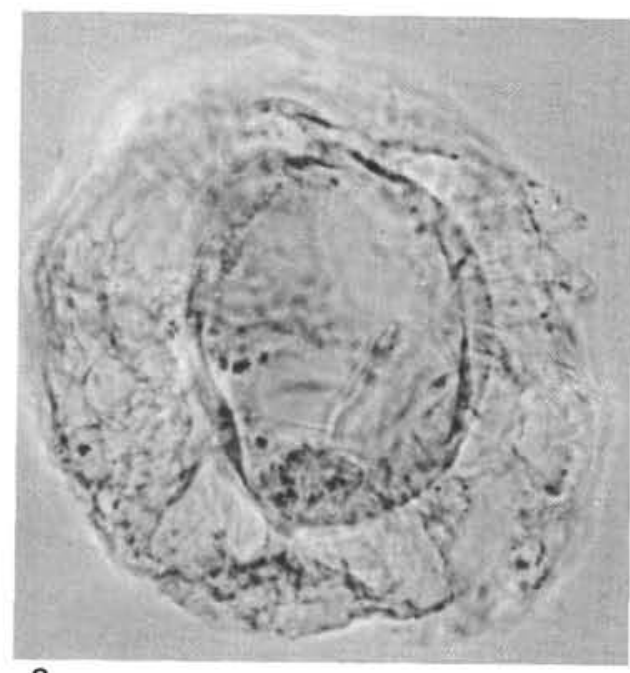

8
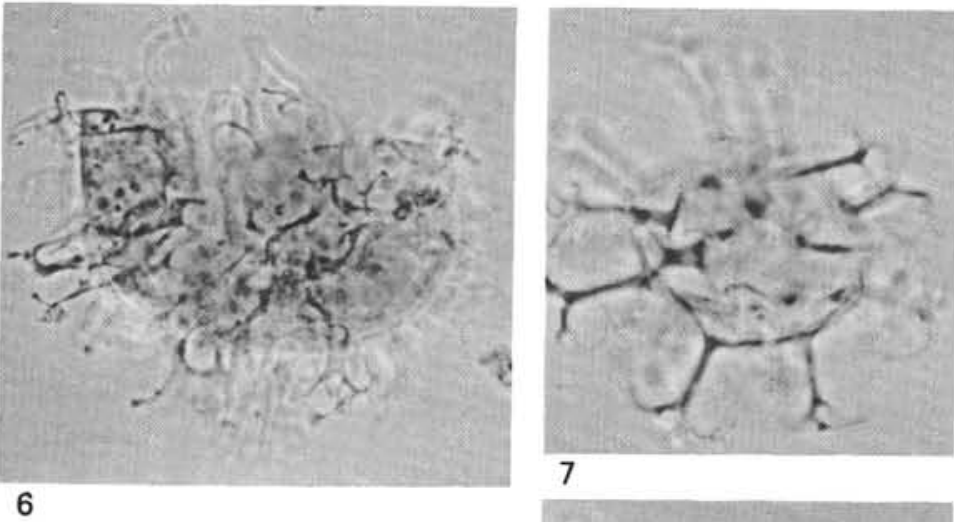

6
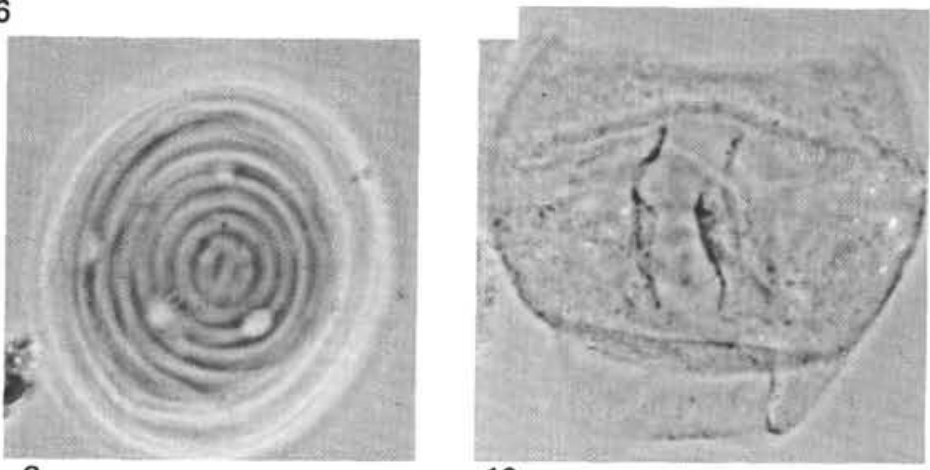

10 


\section{PLATE 2}

Figure 1 Chiropteridium conispinum sp. nov., holotype, dorsal surface, Oligocene, Site $370 . \times 500$; GSC No. 47855 .

Figure 2 Chiropteridium conispinum sp. nov., holotype, ventral surface, Oligocene, Site 370 . $\times 500$.

Figure 3 Chiropteridium conispinum sp. nov., paratype, dorsal surface, Oligocene, Site $370 . \times 500$; GSC No. 47856.

Figure 4 Chiropteridium conispinum sp. nov., paratype, dorsal surface, Oligocene, Site $370 . \times 500$; GSC No. 47857.

Figure 5 Chiropteridium conispinum sp. nov., paratype, ventral surface, Oligocene, Site $370 . \times 500$.

Figure 6 Chiropteridium conispinum sp. nov., paratype, ventral surface, Oligocene, Site $370 . \times 500$.

Figure 7 Chiropteridium dispersum Gocht, Oligocene, Site 370. $\times 500$; GSC No. 47858.

Figure $8 \quad$ Cleistosphaeridium sp., Valanginian, Site 370. $\times 800$; GSC No. 47859 .

Figure 9 Cleistosphaeridium huguonioti (Valensi) Davey, early Cenomanian, Site 370. ×1300; GSC No. 47860 .

Figure 10 Cribroperidinium muderongense (Cookson and Eisenack) Davey, Aptian, Site $370 . \times 500$; GSC No. 47861.

Figure 11 Cribroperidinium muderongense (Cookson and Eisenack) Davey, Aptian, Site $370 . \times 500$; GSC No. 47862. 
PLATE 2

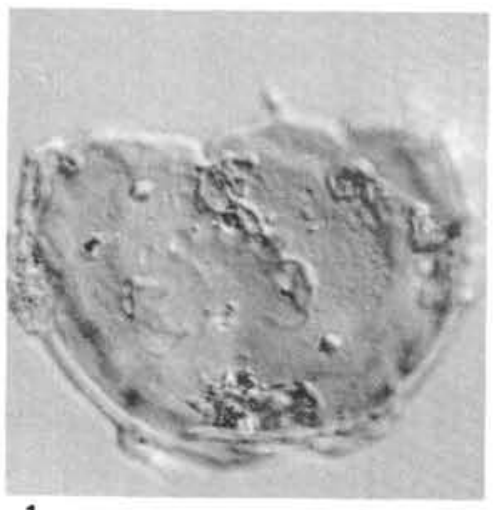

1

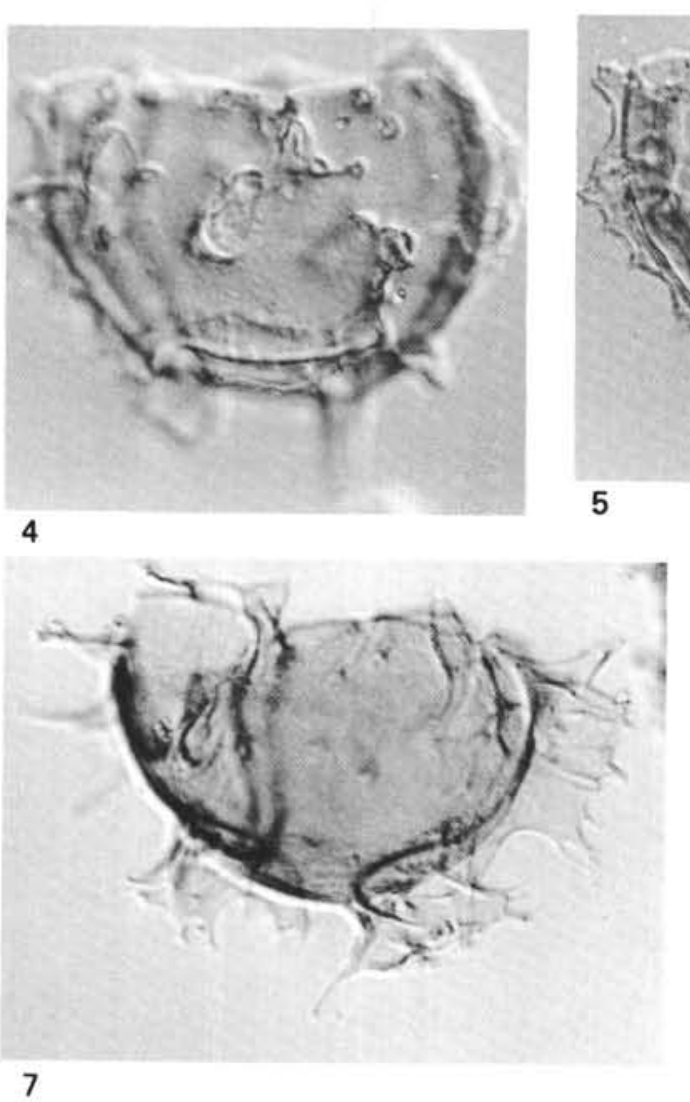

4

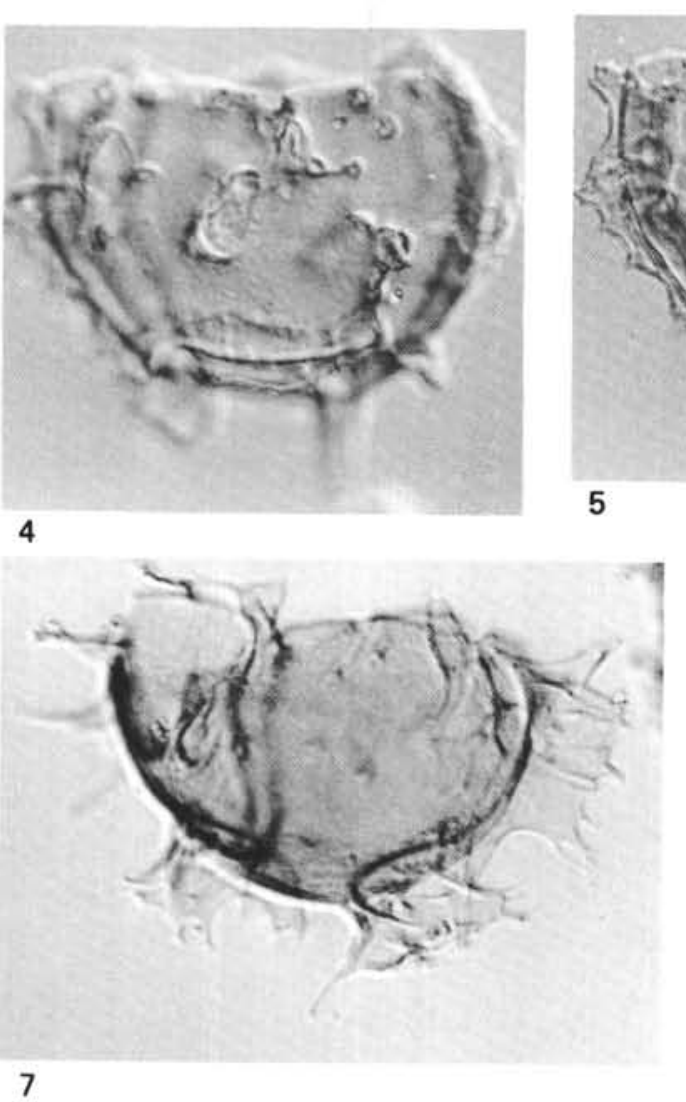

7

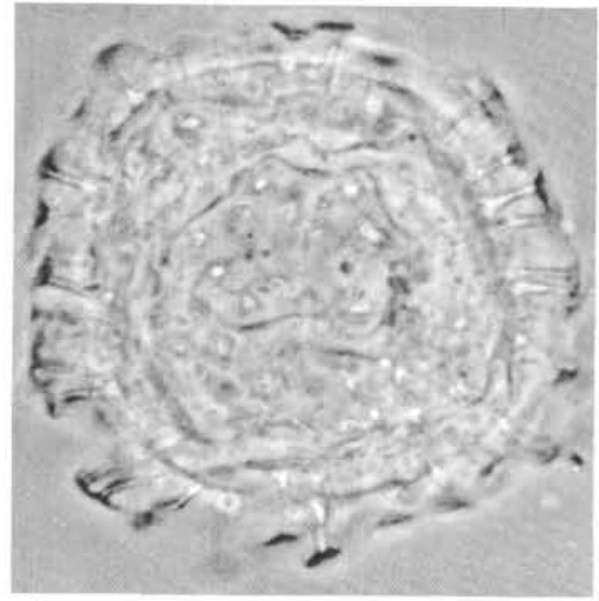

9

2
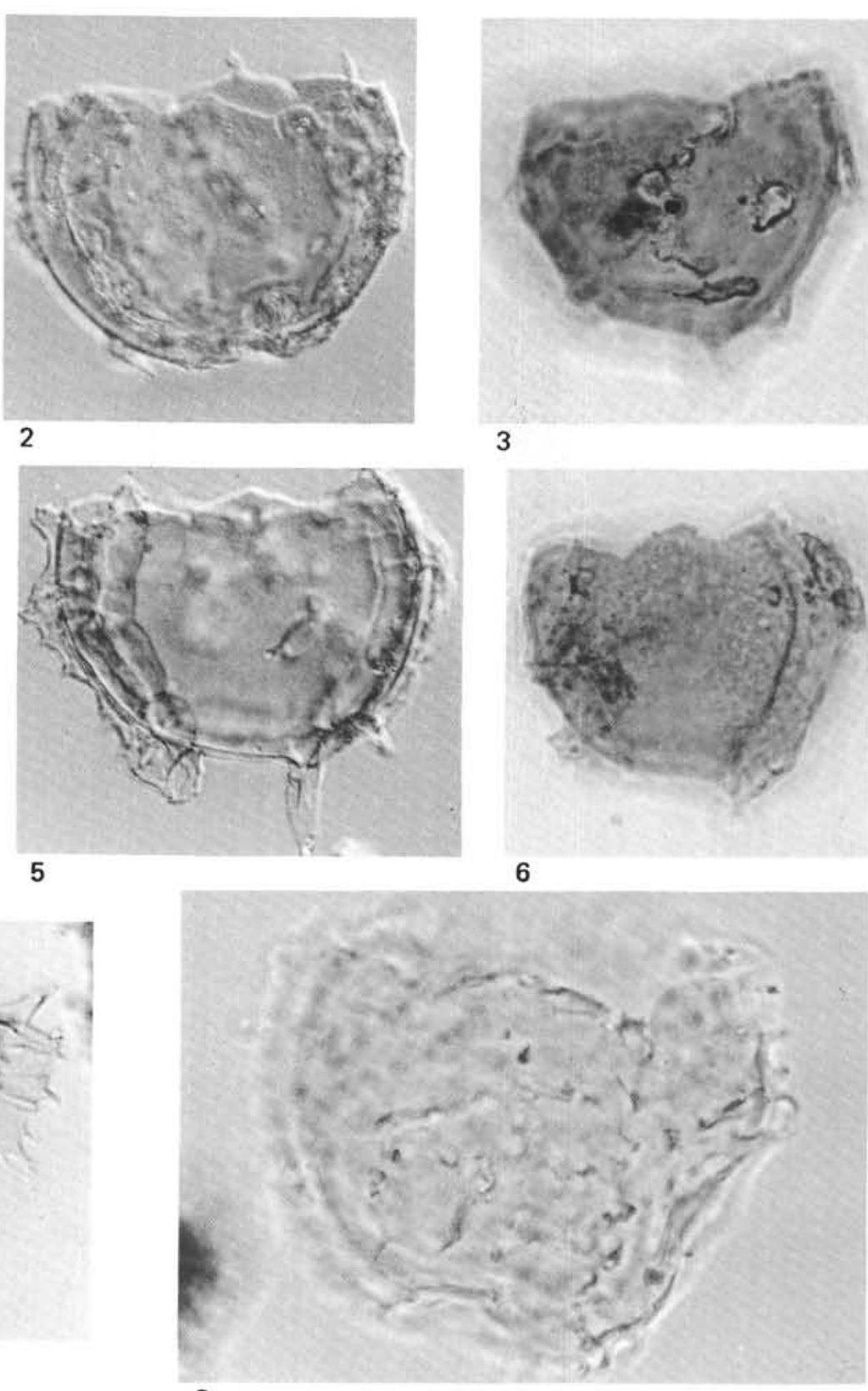

8
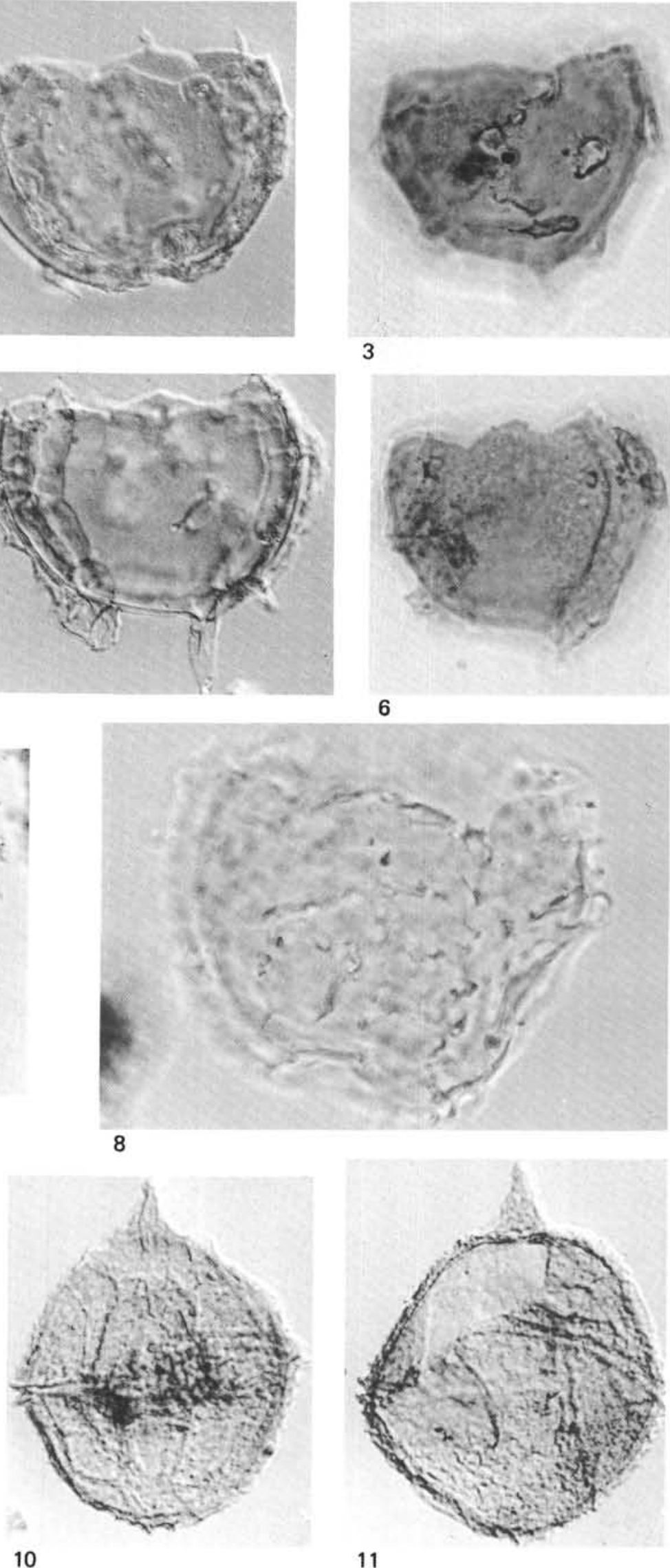

3
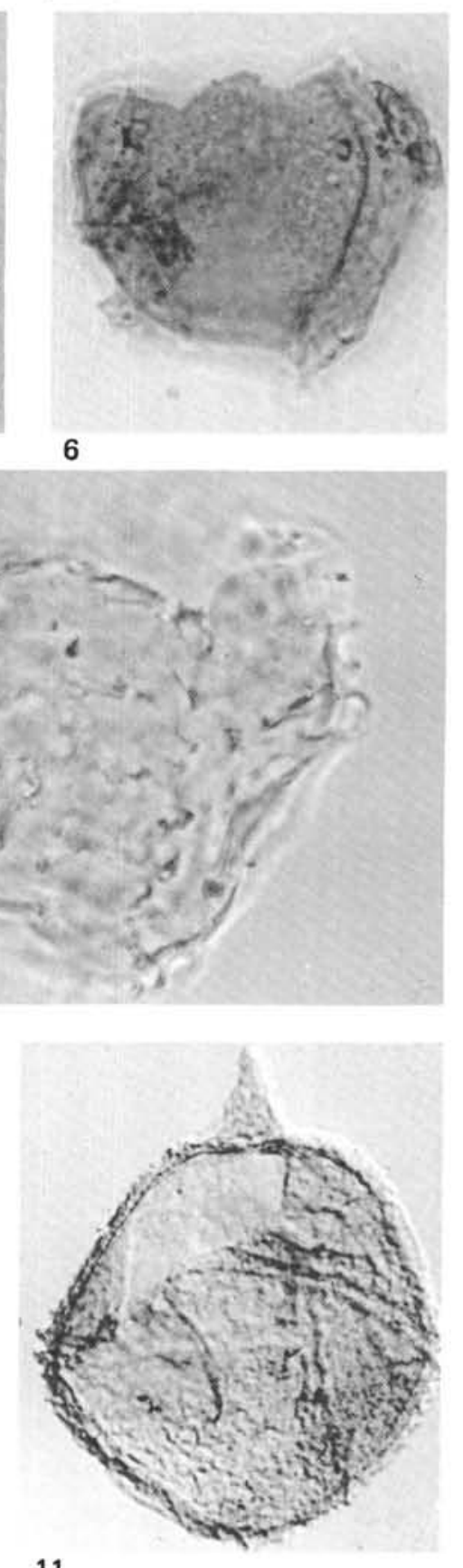

11 


\section{PLATE 3}

Figure 1 Cleistosphaeridium sp. Valanginian, Site 370. $\times 800$; GSC No. 47863 .

Figure 2 Cleistosphaeridium sp. Valanginian, Site 370 $\times 800$; GSC No. 47864.

Figure 3 Cribroperidinium orthoceras (Eisenack) Davey, Aptian, Site 370. $\times 500$; GSC No. 47865 .

Figure 4 Cleistosphaeridium sp. Valanginian, Site 370. $\times 800$; GSC No. 47866 .

Figure 5 Cyclonephelium attadalicum Cookson and Eisenack, Hauterivian, Site 370 . $\times 800$; GSC No. 47867.

Figure $6 \quad$ Chlamydophorella sp. Kimmeridgian, Site 367. $\times 1300$; GSC No. 47868 . 

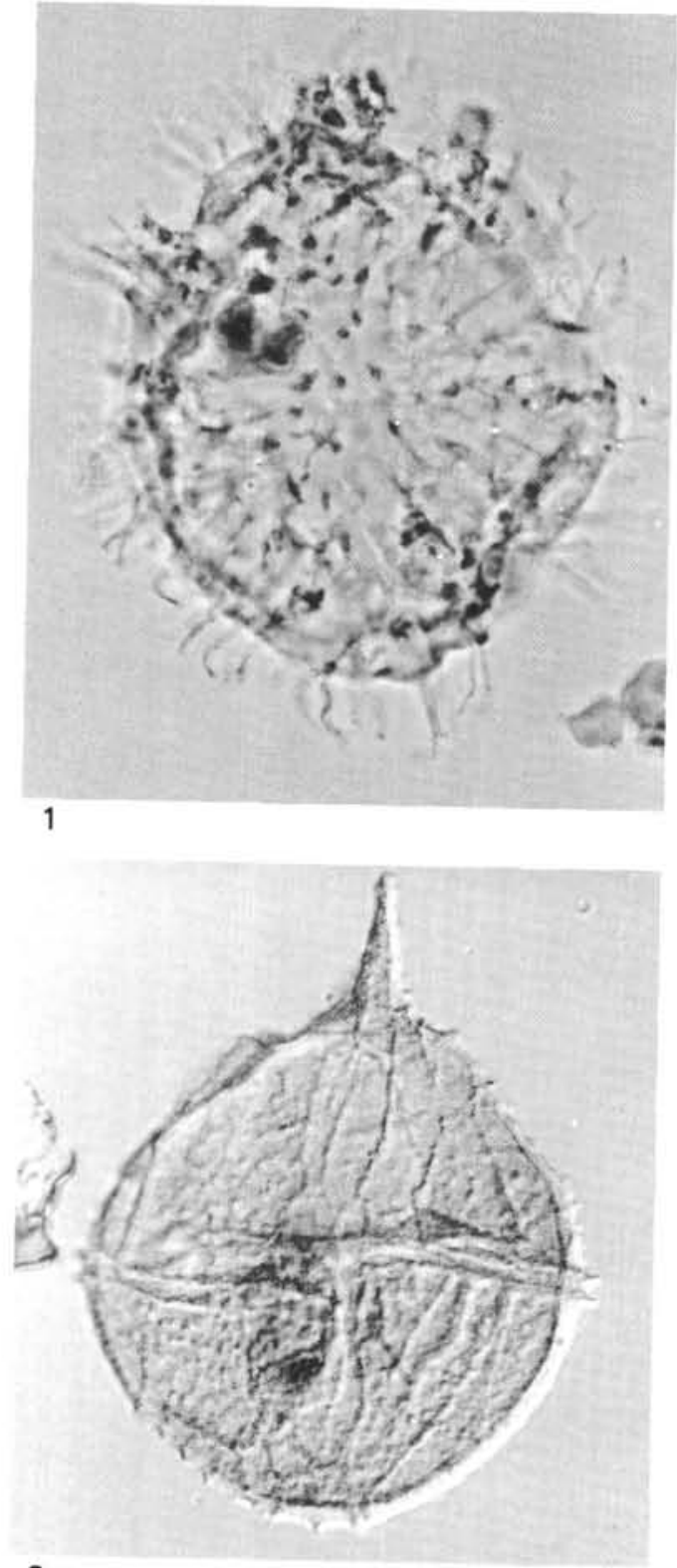

3

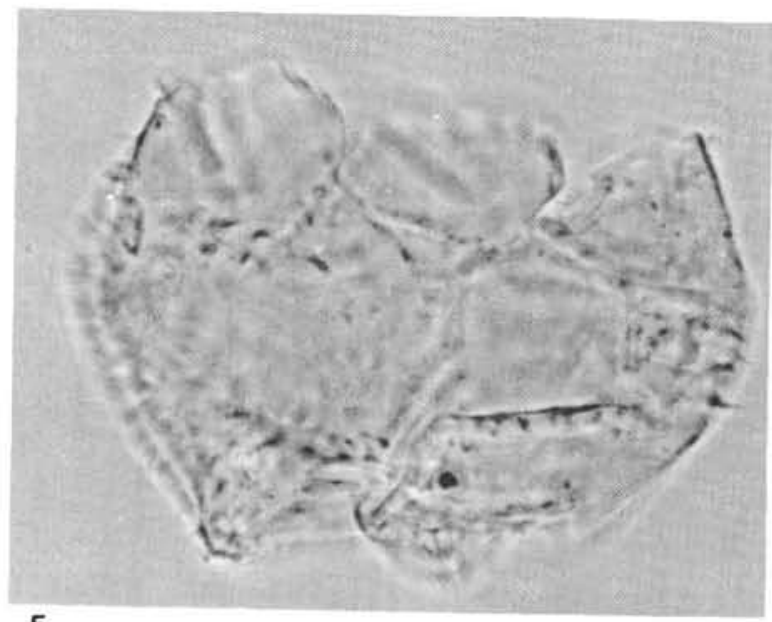

Plate 3
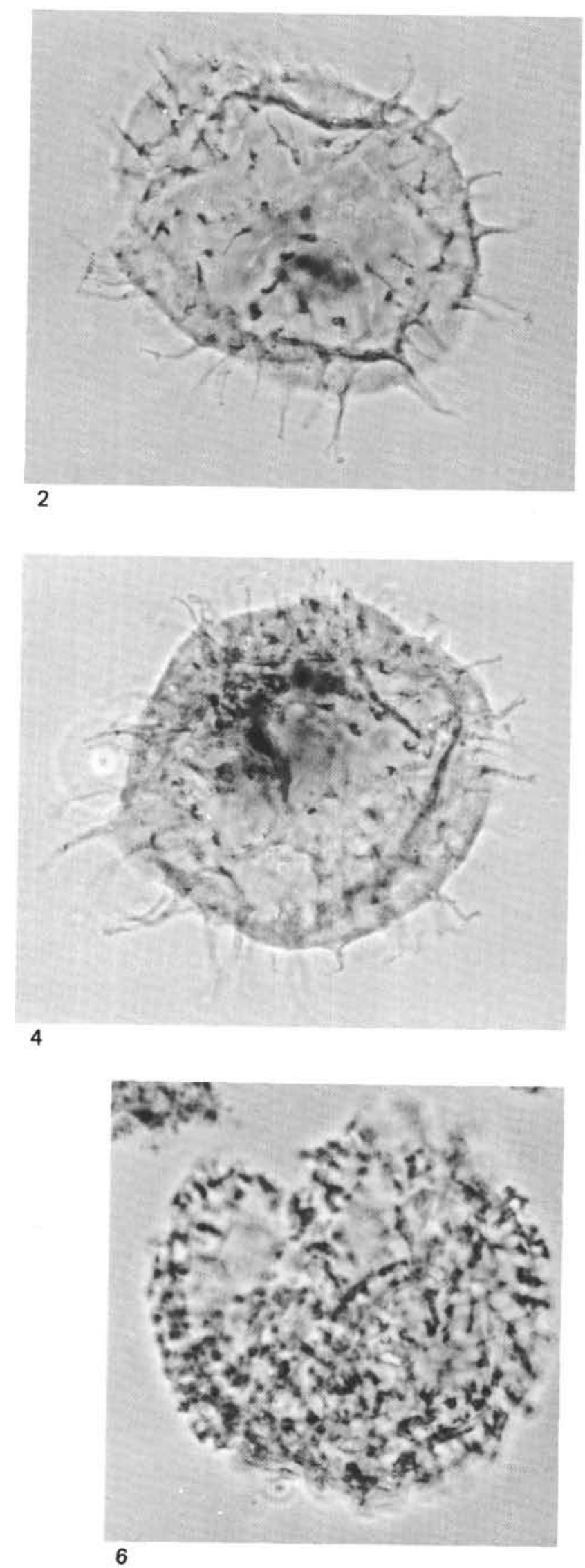


\section{PLATE 4}

Figure 1 Cyclonephelium eisenacki Davey, Albian, Site 370. $\times 800$; GSC No. 47869.

Figure 2 Cyclonephelium vannophorum Davey, middle-late Cenomanian, Site 370. $\times 500$; GSC No. 47870.

Figure 3 Cyclonephelium retiintextum Cookson, middle Eocene, Site $370 . \times 500$; GSC No. 47871 .

Figure $4 \quad$ Cyclopsiella cf. elliptica Drugg and Loeblich, late Eocene, Site 370. ×800; GSC No. 47872.

Figure $5 \quad$ Homotryblium aculeatum sp. nov., paratype, late Eocene, Site 370. $\times 500$; GSC No. 47874.

Figure 6 Homotryblium aculeatum sp. nov., paratype, middle Eocene, Site 370. $\times 500$; GSC No. 47875.

Figure 7 Hystrichodinium pulchrum Deflandre, Valanginian, Site 370. $\times 500$; GSC No. 47877.

Figure 8 Homotryblium aculeatum sp. nov., paratype, middle Eocene, Site 370 . $\times 500$; GSC No. 47876 .

Figure 9 Homotryblium aculeatum sp. nov., holotype, middle Eocene, Site 370. $\times 500$; GSC No. 47873 .

Figure $10 \quad$ Hystrichokolpoma eisenacki Williams and Downie, Oligocene, Site $370 . \times 500$; GSC No. 47878 .

Figure 11 Litosphaeridium siphoniphorum (Cookson and Eisenack) Davey and Williams, basal Cenomanian, Site 370. $\times 800$; GSC No. 47879 .

Figure 12 Lanternosphaeridium radiatum Morgenroth, middle Eocene. Site 370. $\times 500$; GSC No. 47880. 
PLATE 4
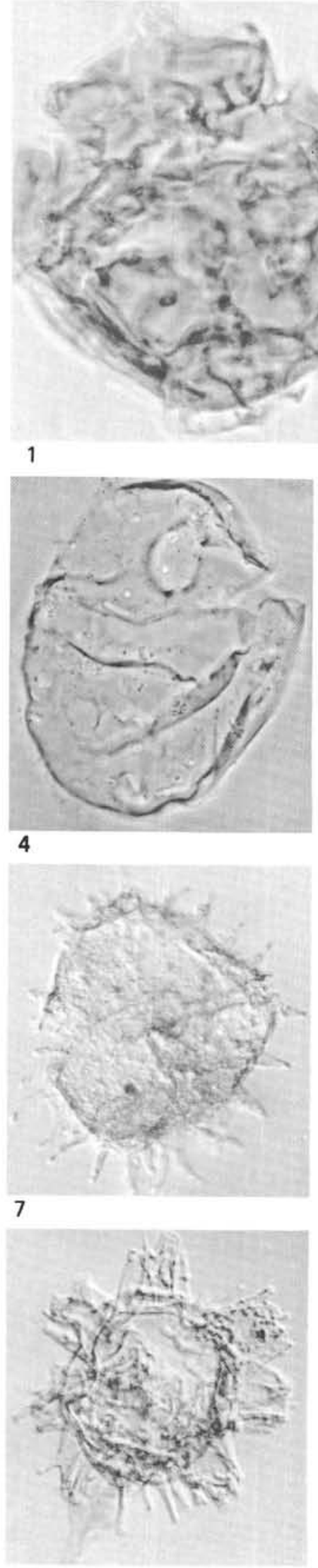

10
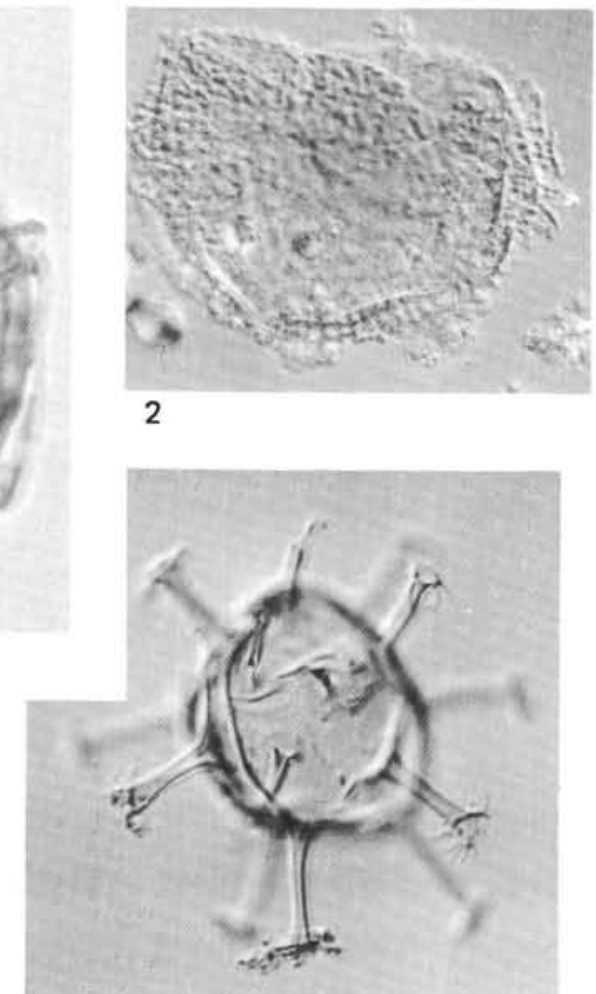

5

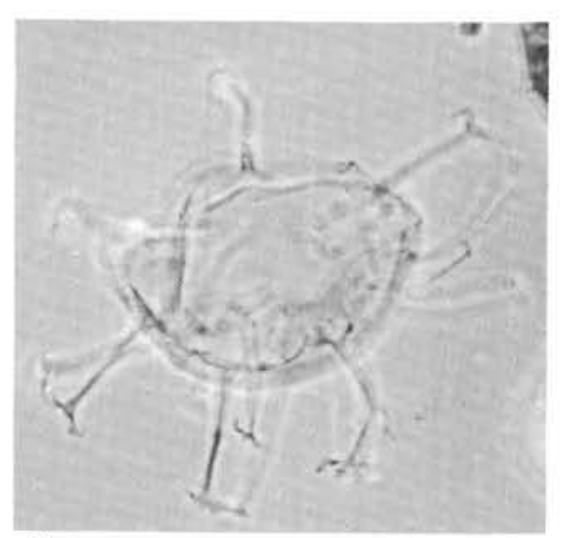

8

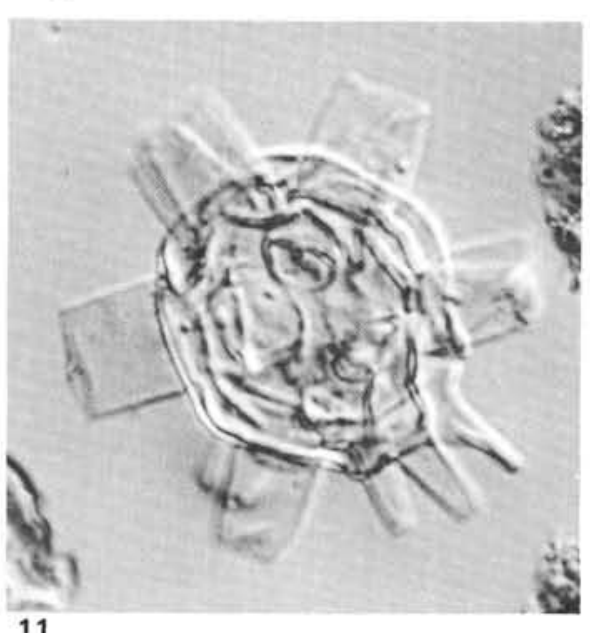

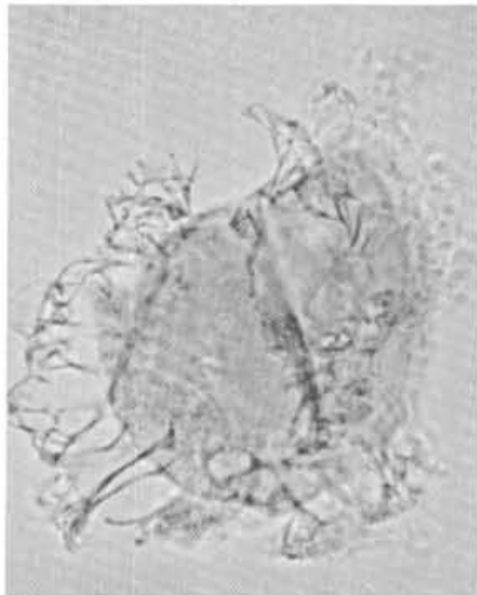

3

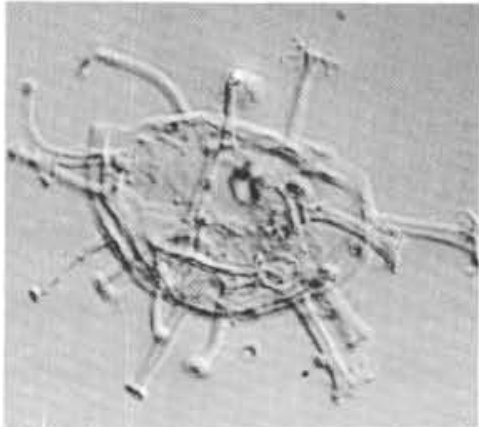

6

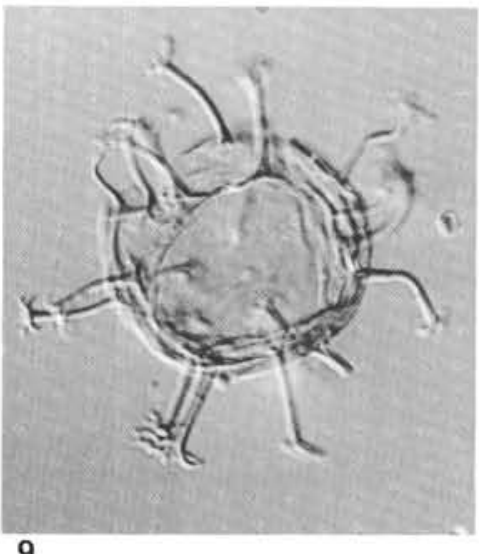

9

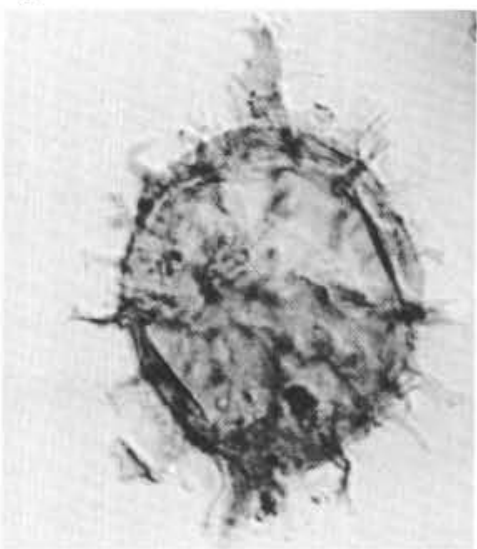

12 


\section{PLATE 5}

Figure 1 Hystrichosphaeridium sp. A Habib, 1972, Portlandian, Site 367. ×1300; GSC No. 47881.

Figure 2 Meiourogonyaulax stoveri Millioud, Hauterivian, Site 370. $\times 800$; GSC No. 47882.

Figure 3 Leptodinium sp. Barremian, Site 367. $\times 800$; GSC No. 47884.

Figure $4 \quad$ Occisucysta sp. A, Hauterivian, Site $370 . \times 500$; GSC No. 47885 .

Figure 5 Meiourogonyaulax stoveri Millioud, Hauterivian, Site 370. $\times 800$; GSC No. 47883.

Figure $6 \quad$ Meiourogonyaulax sp. Aptian, Site 370. $\times 500$; GSC No. 47886.

Figure $7 \quad$ Oligosphaeridium cf. complex (White) Davey and Williams, Hauterivian, Site $370 . \times 500$; GSC No. 47887.

Figure $8 \quad$ Oligosphaeridium dividuum sp. nov., holotype, Valanginian, Site 370 . $\times 500$; GSC No. 47891 .

Figure 9 Oligosphaeridium complex (White) Davey and Williams, Albian, Site 370. ×500; GSC No. 47888.

Figure $10 \quad$ Oligosphaeridium cf. complex (White) Davey and Williams, Hauterivian, Site $370 . \times 500$; GSC No. 47889 .

Figure $11 \quad$ Oligosphaeridium cf. complex (White) Davey and Williams, Hauterivian, Site $370 . \times 500$; GSC No. 47890 . 


\section{PLATE 5}

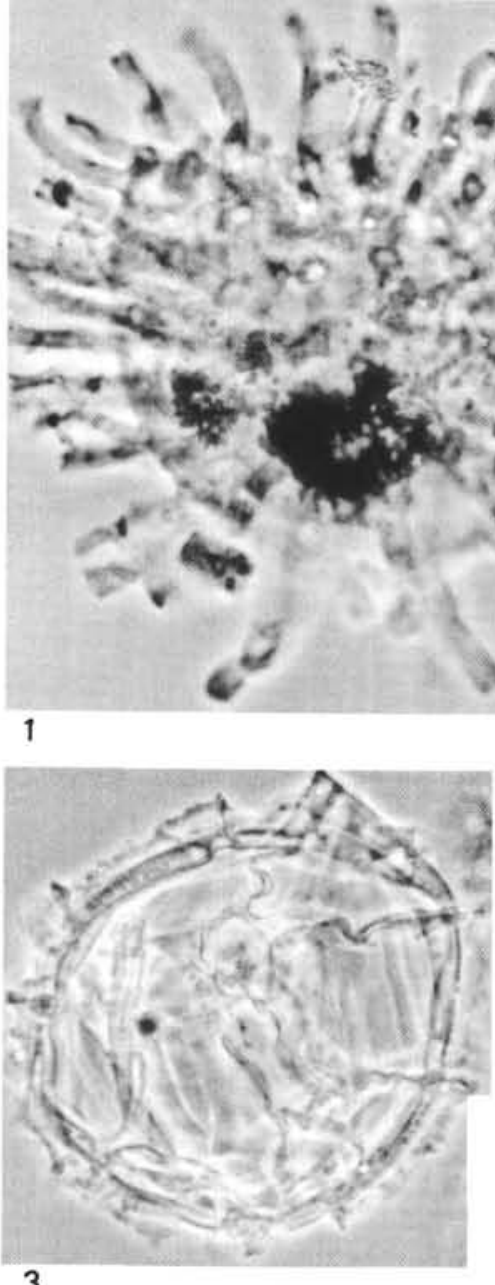

3

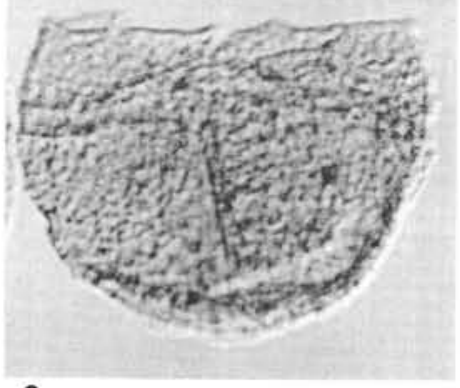

6

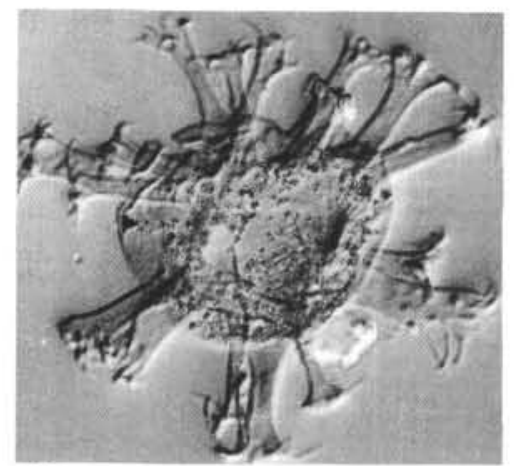

9

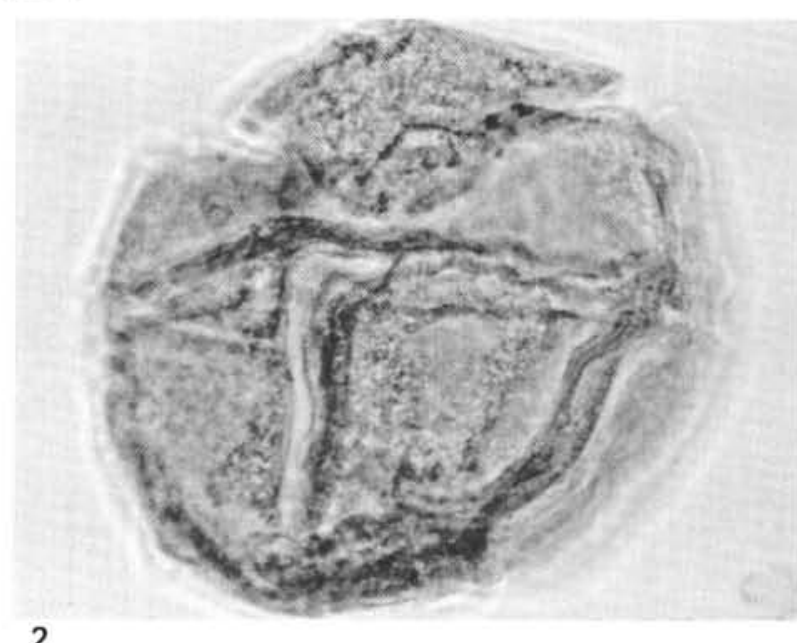

2
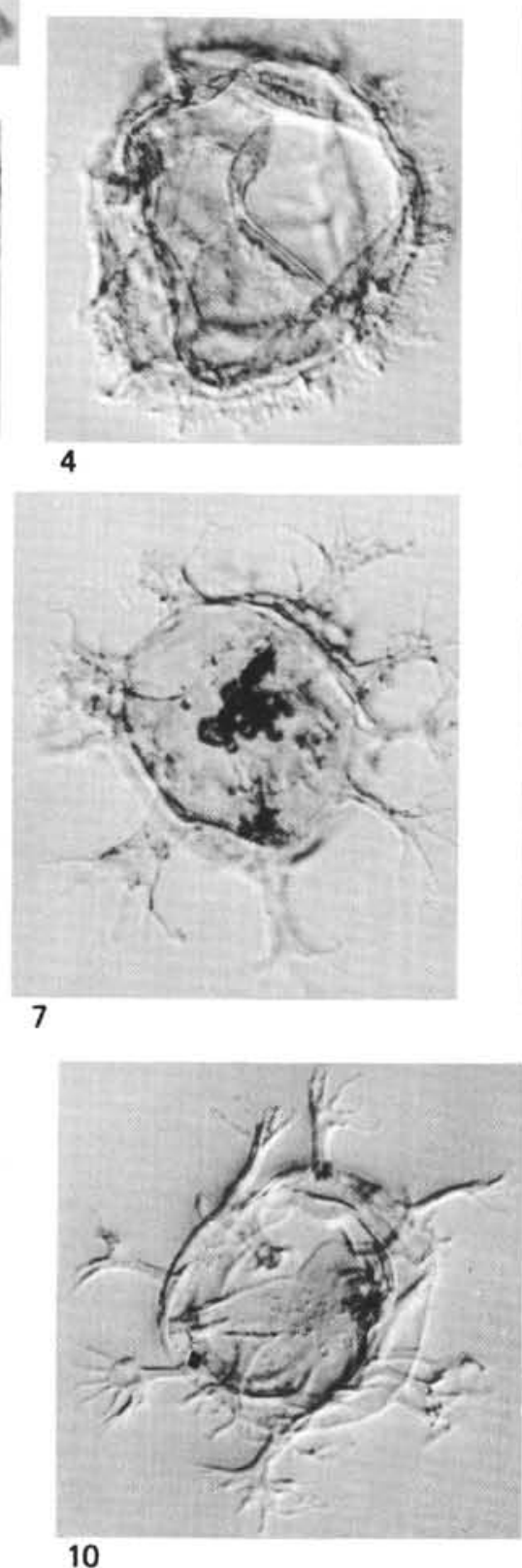

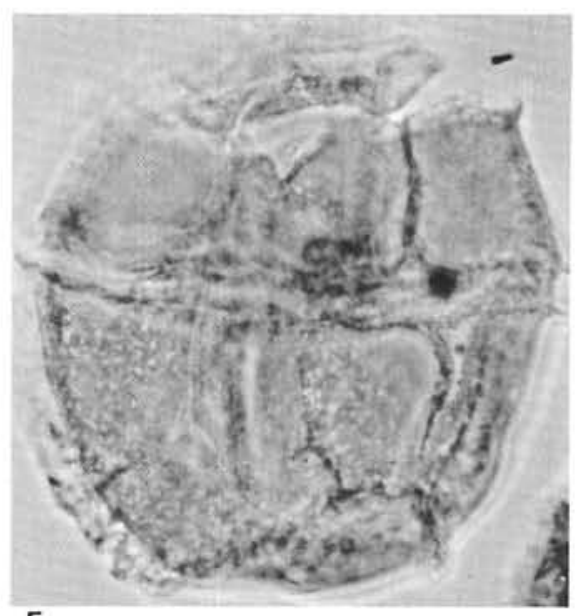

5

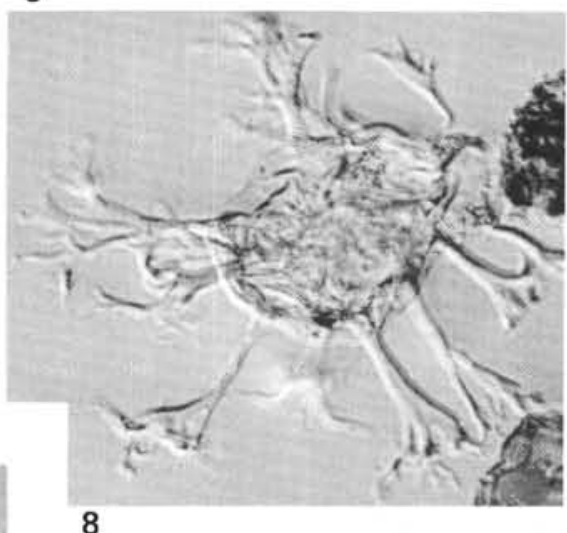

8

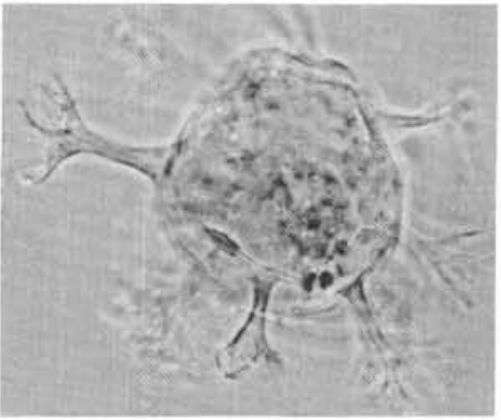




\section{PLATE 6}

Figure 1 Oodnadattia tuberculata Eisenack and Cookson, 1960, middle-late Cenomanian, Site $370 . \times 800$; GSC No. 47892.

Figure 2 Ovoidinium scabrosum (Cookson and Hughes) Davey, basal Cenomanian, Site $370 . \times 800$; GSC No. 47893.

Figure 3 Fungal Spore, middle-late Cenomanian, Site 370. $\times 800$; GSC No. 47894 .

Figure $4 \quad$ Scriniocassis dictyotum (Cookson and Eisenack) Beju, Kimmeridgian, Site 367. $\times 500$; GSC No. 47895 .

Figure $5 \quad$ Prolixosphaeridium granulosum (Deflandre) Davey et al., Aptian, Site 370. $\times 800$; GSC No. 47896.

Figure 6 Schematophora speciosa Deflandre and Cookson, late Eocene, Site 370. ×800; GSC No. 47897.

Figure 7 Pentadinium laticinctum Gerlach, Oligocene, Site 370. $\times 500$; GSC No. 47898.

Figure $8 \quad$ Scriniocassis dictyotum (Cookson and Eisenack) Beju, Kimmeridgian, Site 367. ×500; GSC No. 47899.

Figure $9 \quad$ Pseudoceratium sp. basal Cenomanian, Site 370. $\times 500$; GSC No. 47900 .

Figure $10 \quad$ Pyxidiella sp. A Habib, 1972, Barremian, Site 367. $\times 800$; GSC No. 47901 .

Figure $11 \quad$ Pyxidiella sp. A Habib, 1972, Kimmeridgian, Site 367. $\times 800$; GSC No. 47902. 
PLATE 6
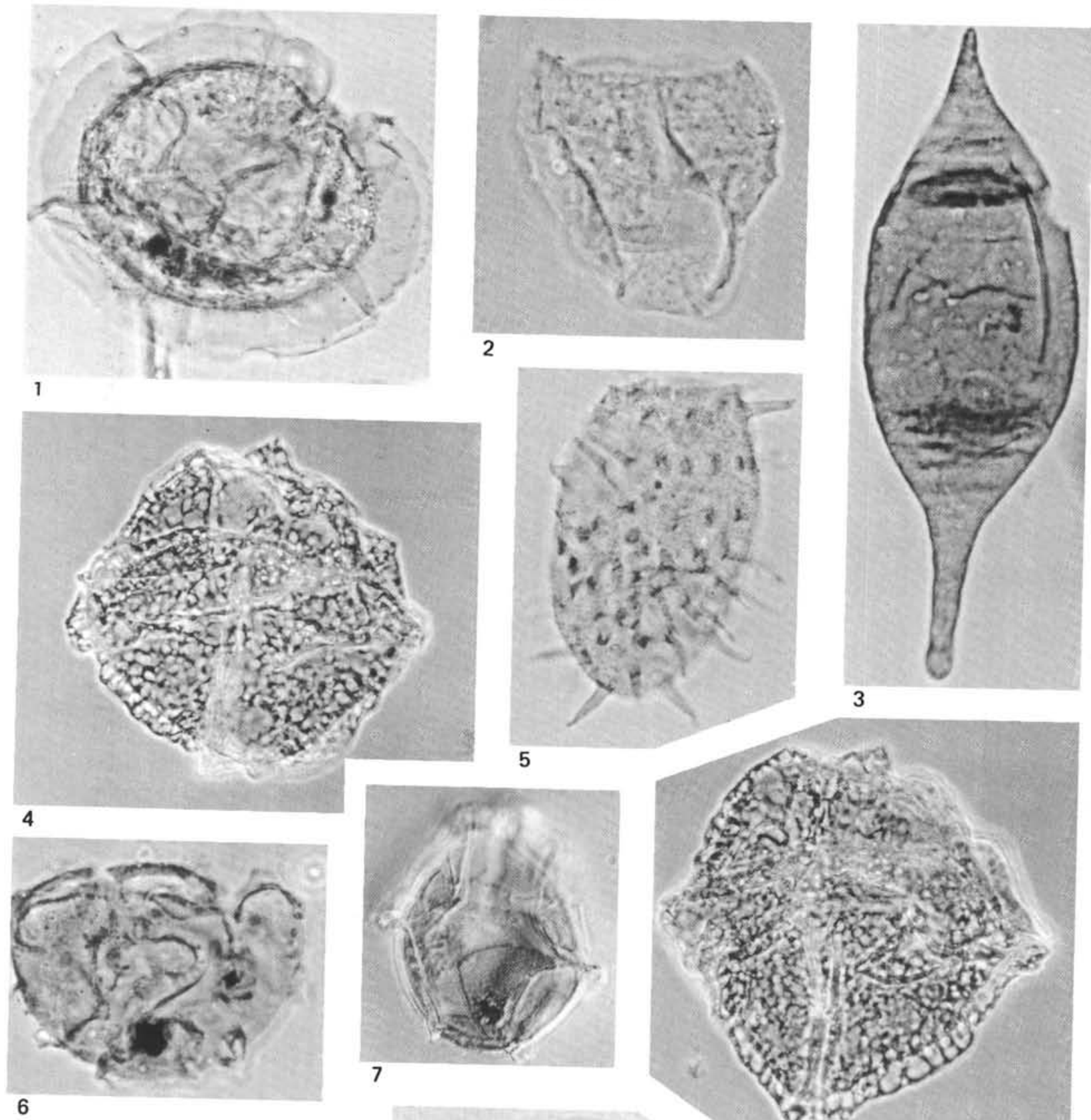

3
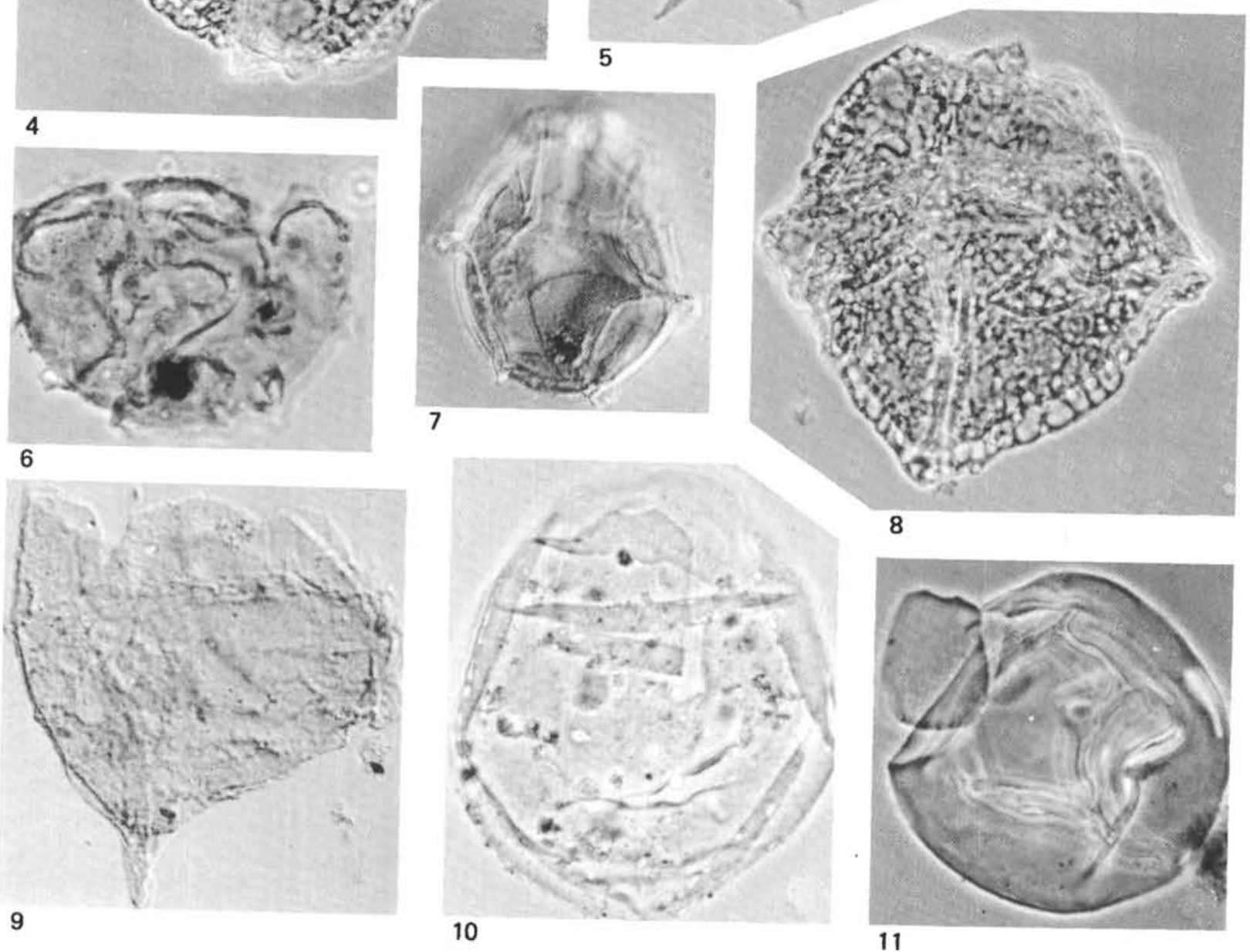


\section{PLATE 7}

Figure $1 \quad$ Subtilisphaera cf. perlucida (Alberti) Jain and Millepied, Aptian, Site 370. $\times 800 ;$ GSC No. 47903.

Figure 2 Palaeohystrichophora sp., middle-late Cenomanian, Site 370. ×800; GSC No. 47904.

Figure 3 Selenopemphix nephroides Benedek, Plio-Pleistocene, reworked, Site 370. ×1300; GSC No. 47905.

Figure 4 ?Vozzhennikovia elegantula sp. nov., early Eocene, Site 370. $\times 800$; GSC No. 47906.

Figure 5 Sirmiodinium grossi Alberti sensu Gitmez and Sarjeant, 1972, Kimmeridgian, Site 367. $\times 800$; GSC No. 47907.

Figure 6 Sirmiodinium grossi Alberti sensu Gitmez and Sarjeant, 1972, Kimmeridgian, Site 367. $\times 800$; GSC No. 47908.

Figure 7 ?Vozzhennikovia elegantula sp. nov., early Eocene, Site 370. $\times 800$; GSC No. 47909.

Figure 8 ?Vozzhennikovia elegantula sp. nov., holotype, early Eocene, Site 370. ×500; GSC No. 47910.

Figure 9 ?Vozzhennikovia elegantula sp. nov., early Eocene, Site 370. $\times 800$, GSC No. 47911.

Figure 10 Vozzhennikovia tenella (Morgenroth) Lentin and Williams sensu Morgenroth, 1966b, pl. 1, fig. 9, Oligocene, Site 370. ×650; GSC No. 47912.

Figure $11 \quad$ Sumatradinium sp., Plio-Pleistocene, Site 370. $\times 500$; GSC No. 47913.

Figure 12 Eisenackia sp., early Cenomanian, Site 370. $\times 800$; GSC No. 47914. 
PLATE 7

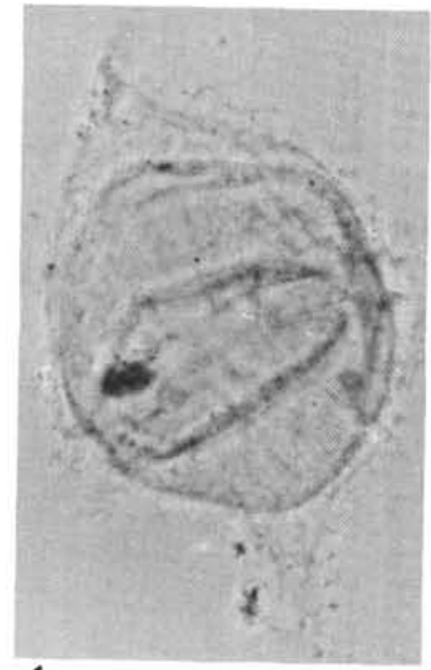

1
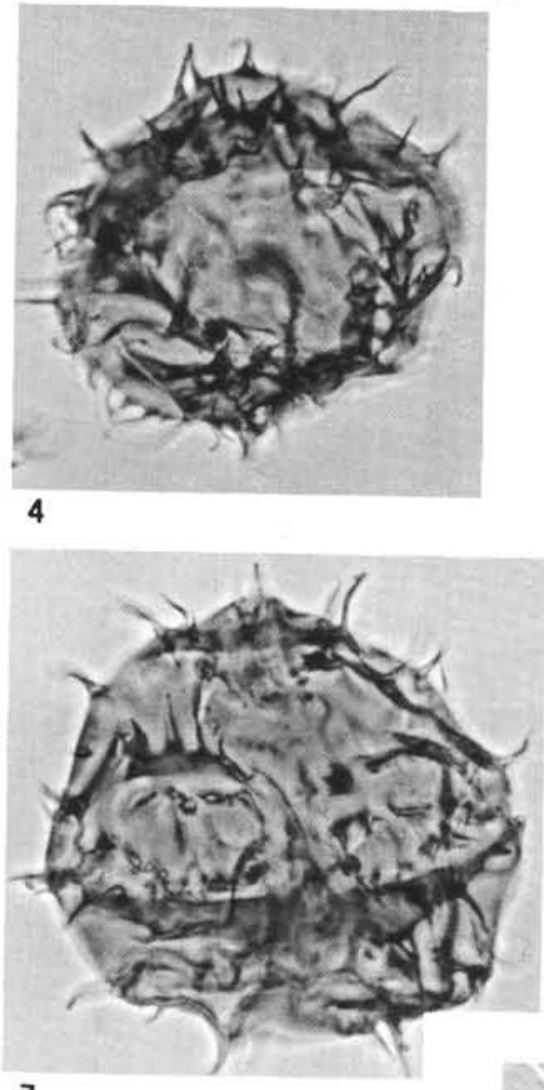

7

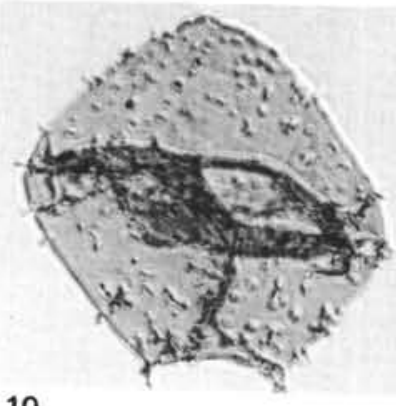

10
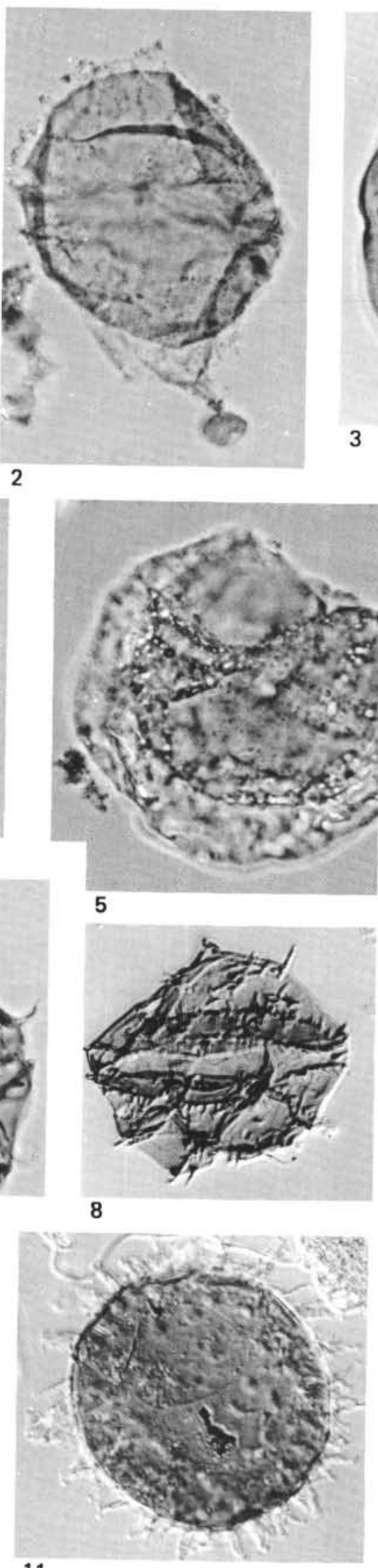

3

5

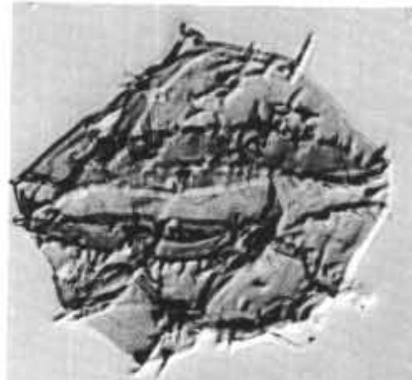

8
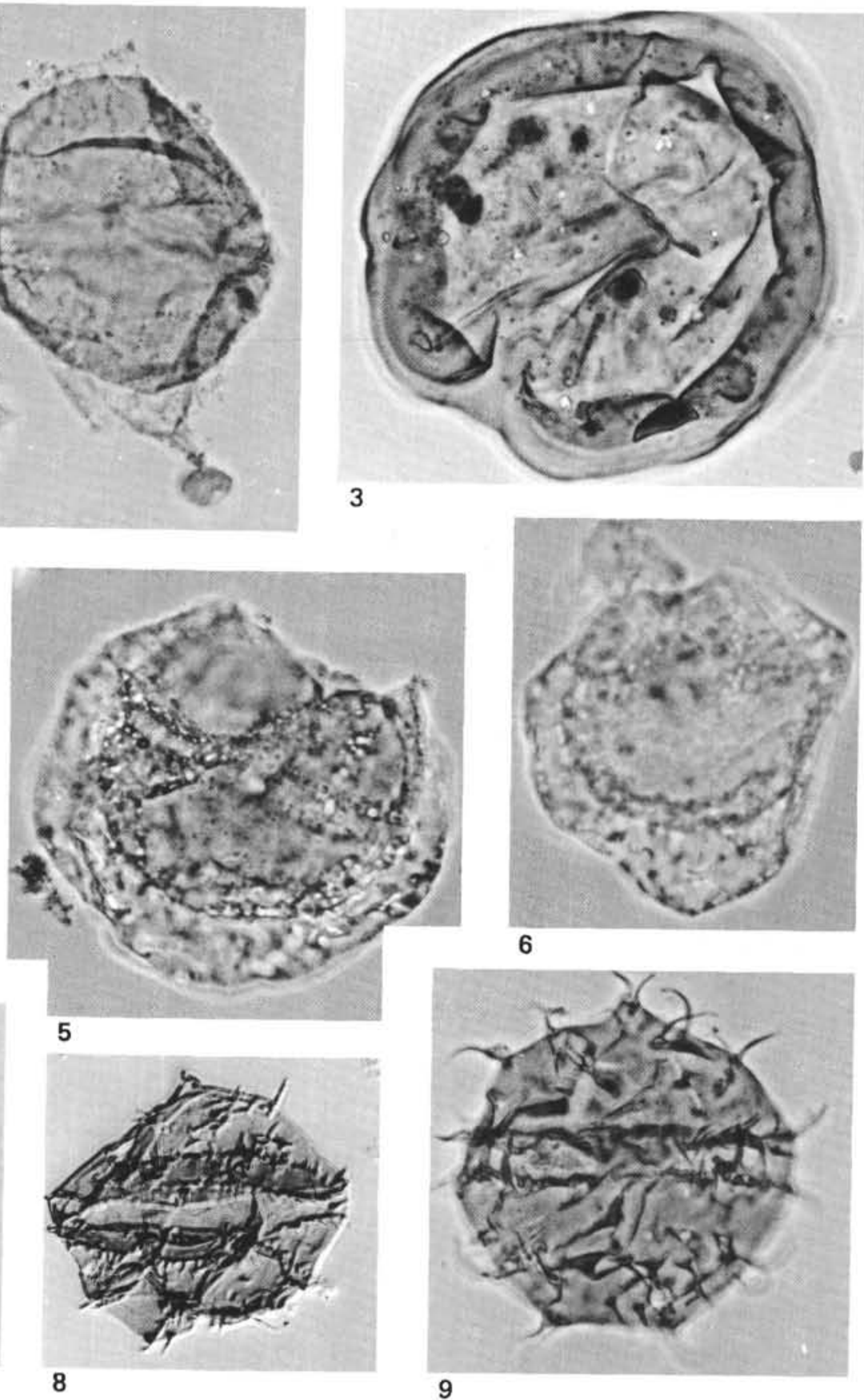

9

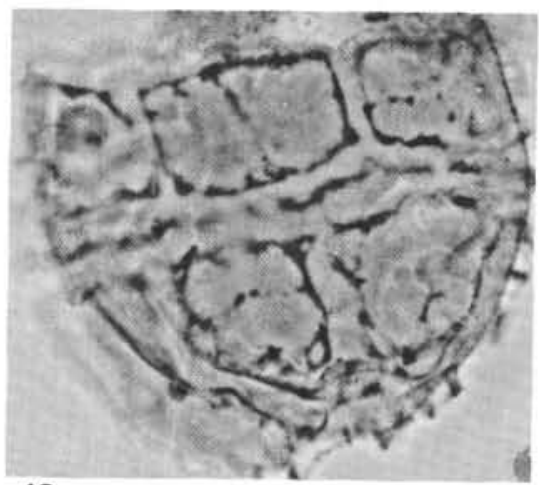

12 


\section{PLATE 8}

Figure 1 Tenua sp. Hauterivian, Site $367 . \times 800$; GSC No. 47915.

Figure 2 Spinidinium densispinatum Stanley sensu Benedek, 1972, Oligocene, Site 370. ×500; GSC No. 47916.

Figure 3 Tenua verrucosa Sarjeant, Barremian, Site 367. $\times 800$; GSC No. 47917.

Figure 4 Wallodinium krutzschi (Alberti) Habib, Hauterivian, Site 367. $\times 800$; GSC No. 47918.

Figure 5 Endoscrinium campanulum (Gocht) Vozzhennikova, Barremian, Site 367. $\times 800$; GSC No. 47919 .

Figure $6 \quad$ Vozzhennikovia tenella (Morgenroth) Lentin and Williams, Oligocene, Site 370. $\times 800$; GSC No. 47920 .

Figure 7 Spinidinium densispinatum Stanley sensu Benedek, 1972, Oligocene, Site 370. $\times 500$; GSC No. 47921.

Figure $8 \quad$ Xiphophoridium alatum (Cookson \& Eisenack) Sarjeant, middle-late Cenomanian, Site $370 . \times 800$; GSC No. 47922.

Figure 9 Galeacornea sp., basal Cenomanian, Site 370. $\times 800$; GSC No. 47923 . 
PLATE 8
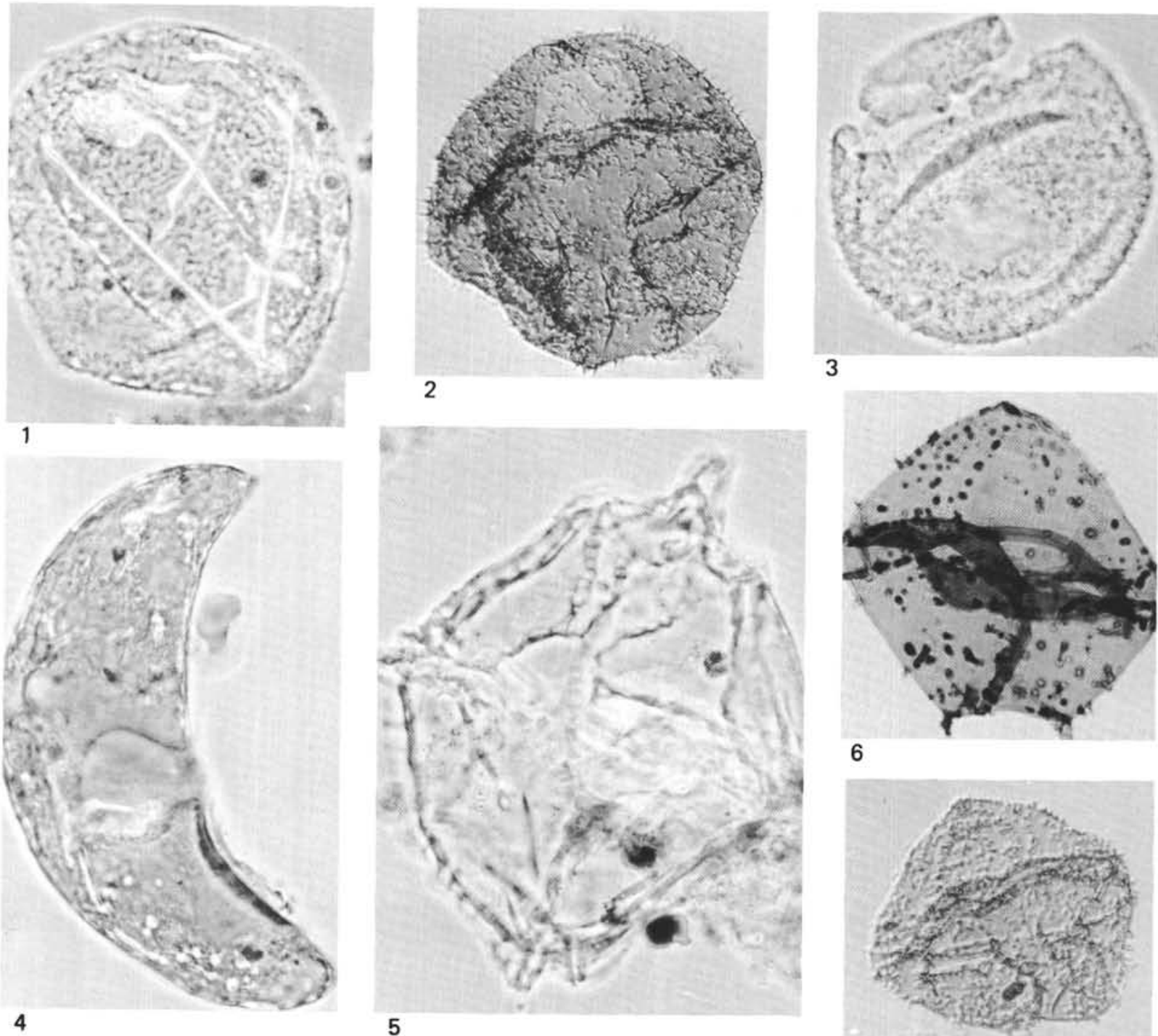

6
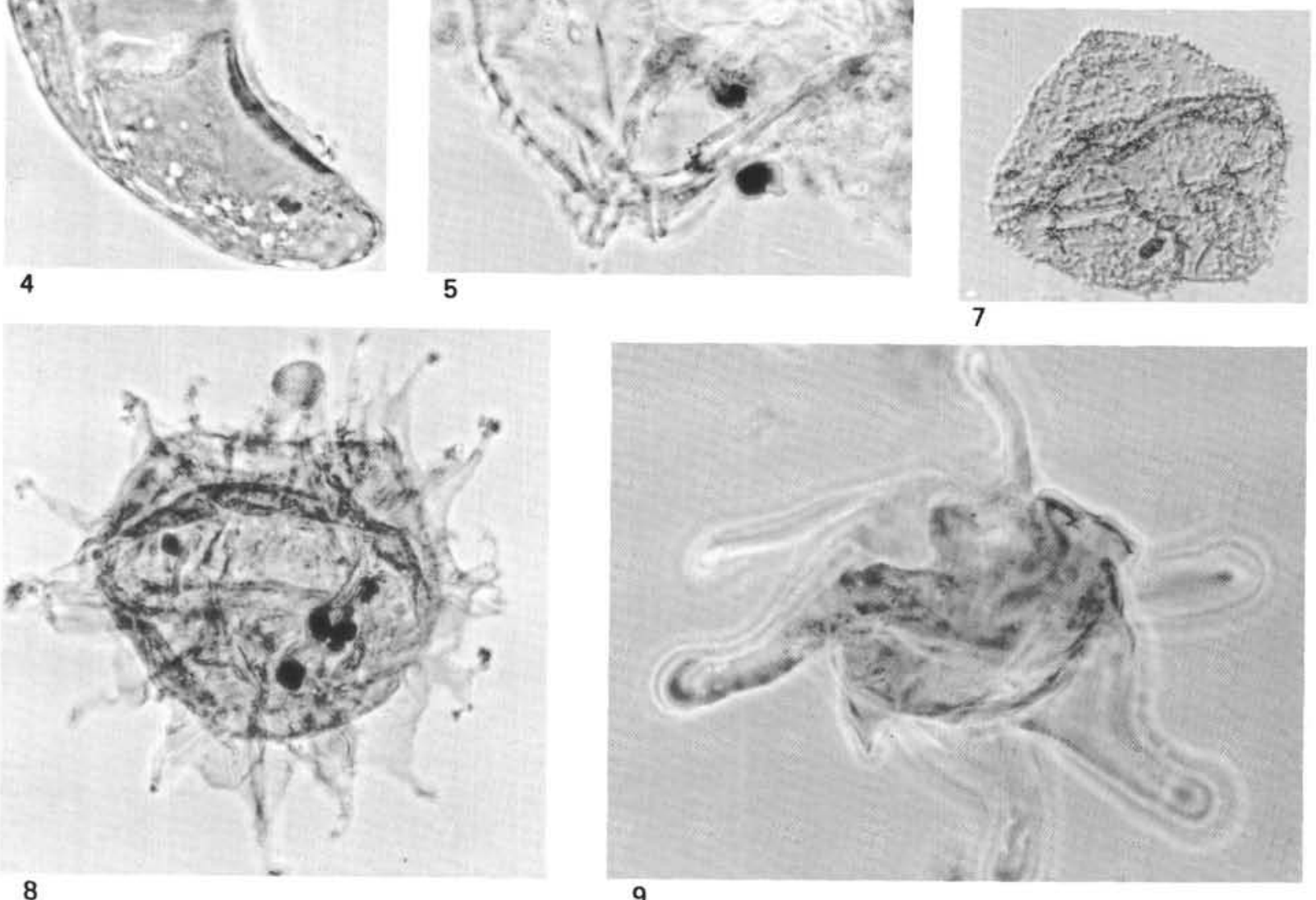